\title{
Title II of the Americans with Disabilities Act After Garrett: Defective Abrogation of Sovereign Immunity and Its Remedial Impact
}

\author{
Matthew D. Taggart†
}

\section{TABLE OF CONTENTS}

Introduction

I Title II, Equal Protection, and the Doctrine of State Sovereign

Immunity

A. Title II of the Americans with Disabilities Act.

B. The Source of Congressional Authority to Enact

Antidiscrimination Laws: The Equal Protection Clause and

Section 5 Enforcement Powers

C. The Rehnquist Court's Use of State Sovereign Immunity as

a Limit on Antidiscrimination Law

I. Abrogating State Sovereign Immunity .............................. 843

a. The Congruence Requirement ................................... 845

b. The Proportionality Requirement ............................... 846

D. Application of the Congruence and Proportionality Test to

Title II by the Circuit Courts Pre-Garrett.

Copyright (C 2003 California Law Review, Inc. California Law Review, Inc. (CLR) is a California nonprofit corporation. CLR and the authors are solely responsible for the content of their publications.

$\dagger \quad$ J.D. Candidate, School of Law, University of California, Berkeley (Boalt Hall), 2003; B.A., French Literature, University of California, San Diego, 1994. Special thanks to Professor Linda Hamilton Krieger for her assistancc with this Comment, and the members of the California Law Review, particularly Heather Weaver, Sara Shaw, and Chris Hazuka, for their thoughtful suggestions. I am indebted to the California Foundation for Independent Living Centers and the many disability rights advocates who have taught me so much about their struggle for independence, specifically Patricia Yeager and Arlene Mayerson of the Disability Rights Education \& Defense Fund ("DREDF"). Thanks also to Professors Larry Levine and John W. Poulos for teaching me why the law matters. This Comment is dedicated to my family and my supportive and amazing friends, most of all Andrea Saunders, Carlo Caoile, Todd Sautner, Alan Fernandes, Dan Murphy, April Barnes, Eva Jabber, Matt Heyn, Dan Zingale, and Linda Chou. Any errors are mine alone. 
1. The Ninth Circuit's Failure to Use Rational Basis Review.. 848

2. The Fourth and Eighth Circuits' Use of Rational Basis Review

II Garrett and Its Implications for Title II of the ADA ……................... 854

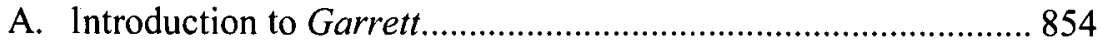

B. Garrett's Implicit Invalidation of Title II ...................................8 856

I. The Supreme Court's Firm Endorsement of Rational

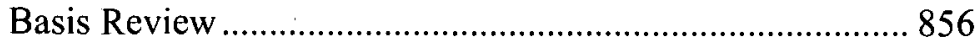

2. The Supreme Court's Scrutiny of the Legislative Record.... 859

3. The Fifth and Tenth Circuits' Garrett-Induced ReversaIs ... 862

III Life After Unconstitutionality? Title II's Remedial Significance in the Post-Garrett Climate

A. The Implausibility of Recovering Money Damages for Intentional Discrimination. 864

B. The Lack of Incentives for People with Disabilities to Pursue Injunctive Relief

C. Scraping the Bottom of the Barrel: The Rehabilitation Act, State Law Remedies, and Section 1983 


\title{
Title II of the Americans with Disabilities Act After Garrett: Defective Abrogation of Sovereign Immunity and Its Remedial Impact
}

\author{
Matthew D. Taggart
}

How this large and diversified group is to be treated under the law is a difficult and often a technical matter, very much a task for legislators guided by qualified professionals and not by the perhaps ill-informed opinions of the judiciary.

Justice White writing for the majority in City of Cleburne $v$. Cleburne Living Center (1985) ${ }^{1}$

\section{INTRODUCTION}

The ability of some fifty-four million disabled Americans ${ }^{2}$ to conduct the most basic daily activities, from using public transit to voting, is in serious jeopardy. The Supreme Court appears willing to find Title II of the Americans with Disabilities Act ("ADA") - the provision of the civil rights law that enables disabled individuals to bring privatc damages suits against states that fail to provide access to public programs, services, and facilities-unconstitutional. By granting certiorari this term in the case of Hason v. Medical Board ${ }^{4}$ the Court was prepared to resolve conclusively the question it purportedly left unanswered in Board of Trustees of University v. Garrett (which involved Title I of the ADA): Did Congress

1. 473 U.S. $432,442-43(1985)$.

2. Census Bureau, U.S. Dep't of Commercc, Census Brief 97-5, Disabilities Affect One-Fifth of All Americans, available at http://www.census.gov/prod/3/97pubs/cenbr975.pdf, available at http://www.census.gov/hhes/www/disability.html (last visited Apr. 1, 2003).

3. The Americans with Disabilities Act of 1990, Pub. L. No. 101-336, 104 Stat. 327 (1990) (codified as amended at 42 U.S.C. $\$ \S 12101-12213(2000)$ ).

4. 279 F.3d I167 (9th Cir. 2002), cert. granted, 123 S. Ct. 561 (2002) (granting certiorari on the question of whether the Eleventh Amendment bars suit under Title II of the ADA against the California Medical Board for denial of a medical license based on the applicant's clinical depression), cert. dismissed, 71 U.S.L.W. 3639 (U.S. Apr. 3, 2003). 
validly abrogate state sovereign immunity in passing Title Il of the ADA? Here, I argue that, based on the Garrett decision, the answer to that question is an emphatic "no." Although the State of California's highly unorthodox last-minute withdrawal of its appeal in Hason $^{6}$ prevented the Supreme Court from ruling Title II unconstitutional this term, I argue here that the provision's fate is already sealed.

An analysis of Garrett and the split of authority among those circuit courts of appeal that have addressed the validity of Title II reveals that there was even less support in the congressional record for Title II than for Title I. After demonstrating why Title II is invalid Section 5 legislation, I consider the fallout likely to follow a holding to this effect. I conclude that Congress's failure to validly abrogate states' sovereign immunity in accordance with the standard set forth in Garrett begets serious consequences for America's disabled by stripping them of the remedial means necessary to enforce their most basic civil rights against state bureaucracies.

Over the past decade, the Supreme Court has wielded its states' rights ${ }^{7}$ jurisprudence to limit legislative power in a variety of areas, particularly in response to certain social legislation. For example, in United States $v$. Lopez $^{8}$ and United States v. Morrison, ${ }^{9}$ the Court held that Congress had

5. Bd. of Trustees of Univ. of Ala. v. Garrett, 531 U.S. 356, 360 n.l (2001) ("We are not disposed to decide the constitutional issue whether Title 11 , which has somewhat different remedial provisions from Title l, is appropriate legislation under $\$ 5$ of the Fourteenth Amendment.").

6. See Associated Press, Supreme Court Cancels Arguments in ADA Case, WASH. Post, March 8,2003 , at A9 ("California had asked the court last year to hear the appeal, then in an unusual move urged the court this month to dismiss the case. Advocates for the disabled lobbied state leaders for the reversal."); David G. Savage, The State, Lockyer Seeks to Avoid High Cout Battle: He Urges the State Medical Board to Back Out of a Discrimination Case that Could Affect the Americans with Disabilities Act, L.A. Times, Feb. 27, 2003, at B7. California Attorney General Lockyer explained this unusual move by saying:

1t is my belief as attorney general that the greater public interest of the state of California would be furthered by a withdrawal of the petition.... I believe that it would be truly unfortunate to have the entirety of the [ADA's] remedial scheme against state discrimination decided in the context of this case's limited focus.

ld.

7. The phrase "states' rights" has been employed by thc legal academy and, occasionally, by the liberal-leaning justices on the Court as a means to categorize the conservative block's sovereign immunity jurisprudence over the past decade and to lampoon these same decisions. See United States v. Morrison, 529 U.S. 598, 654 (2000) (5-4 decision) (Souter, J., dissenting) (noting that thirty-six of the states no longer required to follow the congressional legislation invalidated by the majority had supported such legislation); Fla. Prepaid Postsecondary Educ. Expense Bd. v. Coll. Sav. Bank, 527 U.S. 627, 665 (1999) (5-4 decision) (Stevens, J., dissenting) ("Until this expansive and judicially crafted protection of States' rights runs its course, I shall continue to register my agreement with the views expressed in the Seminole dissents and in the scholarly commentary on that case."); Robert F. Nagel, The Future of Federalism, 46 CASE WEsr. L. Rev. 643, 645 (1996) (describing how, after United States v. Lopez, 514 U.S. 549 (1995), "[s]tates' rights seem at least momentarily ascendant").

8. 514 U.S. 549 (1995). Lopez is viewed by many as the turning point in the Court's fcderalism-states' rights jurisprudence, as it was the first decision in nearly fifty years to hold that Congress exceeded its commerce power in enacting social legislation. Compare Erwin Chemerinsky, The Federalism Revolution, 31 N.M. L. Rev. 7 (2001), with Steven G. Calabresi, A Government of Limited and Enumerated Powers: In Defense of United States v. Lopez, 94 MicH. L. REv. 752 (1995). 
exceeded its commerce power in enacting, respectively, the Gun Free School Zones Act of $1990^{10}$ and the Violence Against Women Act of 1994." And in City of Boerne v. Flores, the Court held that Congress had surpassed its Section 5 enforcement power under the Fourteenth Amendment because the protections contained in the antidiscrimination legislation at issue did not track closely enough with the substantive protections of Section 1 of the Fourteenth Amendment as defined by the Court in prior precedents. ${ }^{12}$

These cases have sparked a scholarly debate over the proper balance of judicial and congressional power. Many legal scholars over the last few years have criticized as paternalistic the Court's view of congressional power to enact social legislation. ${ }^{13}$ Most agree that the prophylactie social legislation invalidated by the Supreme Court in these and subsequent cases once would have been considered unassailable. ${ }^{14}$ Until recent years, the Court applied (for example, in the well-known cases, Heart of Atlanta Motel, Inc. v. United States,${ }^{15}$ Katzenbach v. McClung, ${ }^{16}$ and Katzenbach $v$. Morgan ${ }^{17}$ ) a highly deferential standard of judicial review to early antidiscrimination laws such as the Civil Rights Act of $1964^{18}$ and the Voting

Professor Erwin Chemerinsky argued that the Rehnquist Court will be defined by the retrenchment of Congress's commerce and Section 5 powers, which began with Lopez. Chemerinsky, supra, at 7. Professor Steven Calabresi, while more enthusiastic about Lopez, agreed that "[e]ven if Lopez produces no progeny and is soon overruled, the opinion has shattered forever the notion that, after fifty years of Commerce Clause precedent, we can never go back to the days of limited national power." Calabresi, supra, at 752.

9. 529 U.S. 598 (2000) (holding that Congress exceeded its commerce power by providing victims of gender-motivated violence with a federal remedy in the Violence Against Women Act of 1994 because the problem addressed was essentially noneconomic in nature).

10. Federal Gun-Free School Zones Act of 1990, Pub. L. No. 101-647, 104 Stat. 4844 (current version at 18 U.S.C. \$ 922(q)(1)-(4) (1994 \& Supp.V1 1998)).

11. Violence Against Women Act of 1994, Pub. L. No. 103-322, 108 Stat. 1902 (codified as amended at 42 U.S.C. $\$ 13701$ (1994)).

12. 521 U.S. 507 (1997), Boerne is discussed infra Part 1.C.1.

13. See, e.g., Ruth Colker \& James J. Brudney, Dissing Congress, $100 \mathrm{MicH}$. L. Rev. 80 (2001) (noting that "the Rehnquist Court has held that Congress exceeded its constitutional authority in five instances during the 2000-2001 Term, on four occasions during the 1999-2000 Term and in a total of twenty-nine cases since the 1994-1995 Term"). See also William W. Buzbee \& Robert A. Schapiro, Legislative Record Review, 54 STAN. L. REv. 87 (2001) (challenging the notion that the Supreme Court's intense review of the legislative record in Garrett is consistent with standards of review in administrative law and arguing instead that it is driven by inappropriate distrust of Congress).

14. Cf. Evan H. Caminker, "Appropriate" Means-Ends Constraints on Section 5 Powers, 53 Stan. L. Rev. 1127, 1133 (2001) ("While the Court upheld a variety of prophylactic Scction 5 measures over the past four decades, the Cour has now held provisions of six federal statutes to be inappropriate exercises of Section 5 power within the past four years alone.").

15. 379 U.S. 241 (1964).

16. 379 U.S. 294 (1964).

17. 384 U.S. 641 (1966) (upholding section 4(e) of the Voting Rights Act ("VRA") of 1965, which prohibited state laws that disqualify non-English speakers from voting, despite the fact that the Equal Protection Clause did not itself, under existing case law, bar English literacy requirements).

18. Civil Rights Act of 1964, Pub. L. No. 88-352, 78 Stat. 241 (codified as amended at 42 U.S.C. $\S 1981$ to $2000 \mathrm{~h}-6(2000))$. 
Rights Act ("VRA") of $1965^{19}$ (even though it should be noted that Title II of the Civil Rights Act of $1964^{20}$ was upheld in Heart of Atlanta and McClung on Commerce Clause grounds). As Justice Brennan noted in Morgan, such antidiscrimination legislation was to be left undisturbed by the judiciary so long as it related to a legitimate end within Congress's inherent (albeit nontextual) powers and the means used to accomplish that end were rational. ${ }^{21}$ Nevertheless, under the rubric of states' rights, the Rehnquist Court has limited the reach of antidiscrimination laws passed under Section 5 by claiming that Congress did not properly abrogate states' Eleventh Amendment sovereign immunity such that the states may be subject to monetary damages in private lawsuits. ${ }^{22}$

As prime Fourteenth Amendment beneficiaries, the disabled have been among those most affected by this trend. In its most far-reaching decision thus far, Board of Trustees of University of Alabama v. Garrett, ${ }^{23}$ the Rehnquist Court ruled that Congress failed to show a sufficient pattern of employment discrimination by states against the disabled that would justify the private money damage claims available under Title I of the ADA. ${ }^{24}$ Applying a slightly stricter variant of the "congruence and proportionality" test first enunciated in City of Boerne v. Flores, ${ }^{25}$ the Court held that the employment discrimination provisions of Title I far exceeded what is needed to remedy unconstitutional (that is, irrational) discrimination against people with disabilities. ${ }^{26}$

Even as the Court has refused to uphold Title I's employment provisions because it could not identify the requisite pattern of historical

19. Voting Rights Act of 1965, Pub. L. No. 107-377, 79 Stat. 437 (codified as amended at 42 U.S.C. $\$ \S 1971-1974 \mathrm{e}(2000))$.

20. 42 U.S.C. $\$ 2000 \mathrm{a}(2000)$ (prohibiting discrimination by so-called "places of public accommodation").

21. Morgan, 384 U.S. at 650 (citing McCulloch v. Maryland, 17 U.S. (4 Wheat.) 316 (1819)). Chief Justice Marshall is credited with putting forth the first formulation of this deferential review in the seminal case of $\mathrm{McC}$ Culloch, which questioned whether the United States could create a national bank even though there was no express textual grant of such power in Article l of the Constitution. Marshall found the act valid under Congress's broad implicit powers granted by the Necessary and Proper Clause. Describing this level of scrutiny, he wrote: "Let the end be legitimate, let it be within the scope of the constitution, and all means which are appropriate, which are plainly adapted to that end, which are not prohibited, but consist with the letter and spirit of the constitution, are constitutional." McCulloch, 17 U.S. at 420 . This type of scrutiny of federal law generally is known as "rational basis" or rationality review.

22. Professors Robert Post and Reva Siegel have characterized the Court's detailed review of the legislative record as a type of strict scrutiny that usually would be reserved for review of state laws that clearly burden so-called "suspect classes" like ethnic and minority groups. See Robert C. Post \& Reva B. Siegel, Equal Protection by Law: Federal Antidiscrimination Legislation After Morrison and Kimel, 110 YALE L.J. 441,477 (2000); infra note 66.

23. 531 U.S. $356(2001)$.

24. See id. at 369 (describing half a dozen specific instances of employment discrimination by states that the respondents in Garrett were able to identify from the ADA's legislative record).

25. 521 U.S. 507 (1997). See text accompanying notes 86-90.

26. Garrett, 53I U.S. at 372-374. 
discrimination by statcs against the disabled, the Court has been silent on the legitimacy of Title II, the far broader "Public Entities" section. This silence has been deafening for the civil rights community because Title II (which acknowledges the status of the disabled as equal citizens and protects their fundamental right to access to state and municipal programs, services, and facilities) is viewed as the bedrock portion of the ADA. ${ }^{27}$ As it is commonly understood that a disabled person first must be able to cross a public street or havc access to public restrooms before he or she can begin to contemplate getting a job, not only are the employment protections of Title I narrower than Title II's "Public Entities" provisions, but they also depend upon the efficacy of Title II's protections.

The Supreme Court's reluctance to rule on the constitutionality of Title II has left a jurisprudential vacuum that the circuit courts have filled with conflicting results. Even before Garrett, most circuit courts agreed that Title II failed to validly abrogate sovereign immunity. Reflecting the prevailing view of the seven circuits that have addressed the matter, the Eighth and Fourth Circuits held or suggested that Title II exceeded Congress's Section 5 power. ${ }^{28}$ Moreover, despite holding prior to Garrett that Title II validly abrogated states' sovereign immunity, ${ }^{29}$ the Fifth and Tenth Circuits reversed those decisions after Garrett to align with the position of the Eighth and Fourth Circuits. ${ }^{30}$ Today, only the Ninth Circuit

27. See 42 U.S.C. $§ \S 12132-12165$ (2000).

28. See Alsbrook v. City of Maumelle, 184 F.3d 999, 1008 (8th Cir. 1999) (en banc) (quoting Boerne, 521 U.S. at 532, for the proposition that Title 11 was not "adapted to the mischief and wrong which the Fourteenth Amendment was intended to provide against"); Brown v. N.C. Div. of Motor Vehicles, 166 F.3d 698, 702-10 (4th Cir. 1999), cert. denied, 531 U.S. 1190 (2001) (holding surcharge regulation invalid under Title 11 without explicitly holding the statute unconstitutional). Accord Garcia v. S.U.N.Y. Health Scis. Ctr., 280 F.3d 98, 111-12 (2d Cir. 2001) (holding that Title 11 failed to validly abrogate state sovereign immunity and that money damage claims may not be brought absent proof of intentional discrimination); Popovich v. Cuyahoga County Court of Common Pleas, 227 F.3d 627, 637 (6th Cir. 2000) (noting that "Congress's characterization of the disabled as a 'discrete and insular minority' in the text of the ADA, 42 U.S.C. $\S 12101$ (a)(7), cannot override Cleburne"); Erickson v. Bd. of Governors, 207 F.3d 945, 948 (7th Cir. 2000). Although Erickson does not deal expressly with Title 11, the Seventh Circuit noted that the sovereign immunity analysis by which it found Title 1 to be unconstitutional under Kimel v. Florida Bd. of Regents, 528 U.S. 62 (2000), overrules Crawford v. Indiana Dep't of Corrections, 115 F.3d 481 (7th Cir. 1997). Crawford previously held Title 11 to be valid. The court stated in Erickson that "if our analogy to the ADEA is precise, then Crawford is no longer authoritative." Erickson, 207 F.2d at 948.

29. Coolbaugh v. Louisiana, 136 F.3d 430 (5th Cir. 1998). In Reikenbacker v. Foster, 274 F.3d 974 (5th Cir. 2001), the Fifth Circuit recognized that the analysis applied by the Supreme Court in Garrett to invalidate Title I also applied to Title 11. Prior to Reikenbacker, the Fifth Circuit relied on the Ninth Circuit's sovereign immunity approach, which the Ninth Circuit continues to apply today. See Coolbaugh, 136 F.3d at 438; Clark v. California, 123 F.3d 1267, 1269 (9th Cir. 1997).

30. See Thompson v. Colorado, 278 F.3d 1020, 1034-35 (10th Cir. 2001), cert. denied, $122 \mathrm{~S}$. Ct. 1960 (2002) (holding Title II invalid by analogy to Garrett); Reikenbacker, 274 F.3d at 979 ("[W]e are persuaded that the Suprcme Court has effectively overruled Coolbangh."). 
adheres to the view that Title Il is justified ${ }^{31}$ in light of the intractable nature of the disability discrimination the statute seeks to prevent..$^{32}$

My goal in this Comment is to show how the Supreme Court, through Garrett, has created a type of sovereign immunity syllogism from which Title II of the ADA cannot possibly escape, ${ }^{33}$ and to demonstrate the importance of this development. The unavailability of money damages is far more serious when dealing with public rather than private entities. First as noted above, public entities provide the services for the disabled upon which interaction with private entities, such as businesses, restaurants, or employers, is predicated. For example, if a city or town fails to provide curb-euts, an individual who relies on a wheelchair for transportation cannot leave her block without the assistance of others. She thus cannot independently vote, shop for groceries, attend movies or soeial events, or participate in Ioeal civic associations. Second, government is not driven by market forces in the same way that private actors are. ${ }^{34}$ Where government is inefficient, damages suits are absolutely critical to Title Il's singular goal of protecting a more fundamental civic equality of the disabled..$^{35}$

31. See infra Part 1.D.1. In Hason v. Medical Board of California, 294 F.3d 1166 (9th Cir, 2002), the court approved its prior precedents holding Title 11 to be valid under Section 5 and denied that Garrett held any implications for Title 11. The court, literally construing Chief Justice Rehnquist's claim in a footnote in Garrett that Title 11 was unaffected by the ruling, refused to change its position. See id. at 1168 (referencing Bd. of Trustees of Univ. of Alabama v. Garrett, 53I U.S. 356, $360 \mathrm{n} .1$ $(2001)$ ). In his scathing dissent to a later denial of en banc review of the panel's opinion, Judge O'Scannlain stated that "today's opinion blithely ignorcs recent Supreme Court precedent and follows superceded cases of our court instead.... [1]t refuses to deal in a meaningful way with intervening Supreme Court precedent, specifically [Garrett]." Hason, 294 F.3d at 1167 (O'Scannlain, J., dissenting).

32. The earlier Ninth Circuit precedents on which Hason relies both upheld Title II as valid on the theory that it was roughly tailored to the goal of preventing irrational discrimination. See Clark, 123 F.3d 1267, 1270-7I; Dare v. California, 19l F.3d 1167, 1173-74 (9th Cir. 1999) (relying on Clark).

33. See Vikram David Amar \& Samuel Estrcicher, Conduct Unbecoming a Coordinate Branch, 4 GREEN BAG 351, 352 (2001). The authors state that "Garrett represents an important loss-not only because of the ADA's importance on the civil rights front, but also becausc the opinion brings to light a problematic methodology." Id. at 353. They agree with the premise of this Comment that "Title II of the ADA, mentioned but not ruled on in Garrett, ... is in jeopardy." ld. at $352 \mathrm{n} .11$ (citation omitted). See also Colker \& Brudney, supra note 13, at 131 ("One can expect future ehallenges to private actions for monetary damages against the States under ADA Title ll.").

34. See generally Richard A. Epstein, Forbidden Grounds: The Case against EMPLOYMEnT Discrimination LAWS 480-94 (1992) (arguing that employment diserimination statutes are unnecessary because private employers who discriminate are acting inefficiently and against their own self-interest). Cf. J. Hoult Verkerke, Free to Search, 105 Harv. L. Rev. 2080, 2082 (1992) ("[E]ven if Epstein's theoretical arguments were convincing, his historical and empirical claims are untenable.").

35. Title 11, despite its accommodation requirements, is predominantly designed to effectuate barrier removal in the public sector. Hence, it may be argued that Title II is Icss entitlement-driven than the other titles of the act. See also, infra notes 59-60. Or, Title II's equality mandate merely requircs the government to treat all citizens equally whereas Title l's employment-provisions mandate may require a private employer to provide certain affirmative modifications to the workplace (in certain cases this has been as extreme as installing an elevator in a two-story restaurant). Title $\mathrm{III}$, in the controversial case of PGA Tour, Inc. v. Martin, 532 U.S. 66I (2001), was used to enable a professional 
This Comment proeeeds in three Parts. Part 1 provides background on the core concepts that relate to Title II's validity under Section Five, which was at issue in the Supreme Court's opinion in Garrett. It begins with a brief sketch of Title Il's overarehing provisions and objeetives and explains why the disability rights community views this particular seetion of the law as so fundamental. It then gives a primer on the Fourteenth Amendment, explaining Congress's authority to enforce it through Section 5 and, in doing so, to abrogate states' sovereign immunity. The Comment then elaborates on the Rehnquist Court's unprecedented use of sovereign immunity to limit the reach of Section 5 law, as manifested in the "congruence and proportionality" test. It concludes with an analysis of how the divergent circuit courts have applied this sovereign immunity analysis to Title II of the ADA, both before and after Garrett.

Part II discusses Garrett's implications for Title II of the ADA. First, it points out that Garrett made indisputably clear that the same "rational basis" review that would normally govern disability discrimination claims brought under the Fourteenth Amendment also drives the inquiry into whether a statute's remedies were sufficiently narrowly tailored to validly abrogate sovereign immunity. Seeond, this Part shows that while the Court did not tackle Title II explicitly in the Garrett opinion, ${ }^{36}$ its sovereign immunity analysis of Title I mirrors that of the circuit courts that have held Title Il unconstitutional. However, Part II suggests that Garrett does more than merely ratify the analyses employed by those circuit courts. In at least one sense, the Garrett opinion directly challenges Title Il's historical justification.

Finally, Part $11 \mathrm{l}$ considers whieh remedies would remain available to the disabled should the Court expressly hold Title II unconstitutional in some future ease, as it seemed prepared to do in Hason prior to that case's

golfer to circumvent tour rules and ride in an electric cart so that he could have "equal" access to professional sports.

Neutral "political equality" has a peculiar place in Fourteenth Amendment jurisprudence. Indeed, the first successful challenges to racial discrimination brought under the Fourteenth Amendment were animated by just such a theory of equality, despite overwhelming hostility to the notion that the Amendment was intended to create racial equality. The Supreme Court pushed slowly toward the broader goals of desegregation by focusing initially on the narrower right of civic equality as opposed to general social equality. Hence, in Strauder v. West Virginia, 100 U.S. (10 Otto) 303 (1879), the Supreme Court's first race discrimination opinion, the Court threw out a state murder conviction of a Black man where a West Virginia statute prevented Blacks from serving on juries. In Plessy $v$. Ferguson, 163 U.S. 537 (1896), Justice Brown's opinion sought to distinguish this kind of equality from the broader right to nonsegregated accommodations on railroad cars, claiming that the Fourteenth Amendment "could not have been intended to abolish distinctions based upon color, or to enforce social, as distinguished from political, equality, or a commingling of the two races upon terms unsatisfactory to either." Id. at 541 .

36. See Garrett, 531 U.S. at 360 n.l. 
dismissal. ${ }^{37}$ If, as Chief Justice Rehnquist states in Garrett, unconstitutionality in the sovereign immunity sense only precludes "money damages" 38 but not injunctive relief, the essential questions become: (1) what exactly does the Supreme Court mean when it refers to "money damages"?; and (2) does an equitable damages regime have enough impact to spur voluntary compliance or to create the kind of political and social equality Title II was meant to create? I ultimately conclude that while plaintiffs may be able to recover money damages for intentional discrimination despite Garrett, most garden-variety access and accommodation claims will result, at most, in a recovery of attorneys' fees and prospective injunctive relief. And there are significant limits on both. As for attorneys' fees, I note that their availability has been severely limited by Buckhannon Board and Care Home, Inc. v. West Virginia Department of Health and Human Resources. ${ }^{39}$ As for suits seeking injunctive relief, I note that there are several important procedural and substantive disincentives to pursuing them. Finally, I note that section 1983 claims against individual state officers, claims brought under the Rehabilitation Act, and state law causes of action are insufficient to fill the huge void left in Title II (due to Congress's failure to validly abrogate state sovereign immunity in enacting it). Essentially, then, without money damages, there is little incentive for states to comply with the ADA voluntarily.

\section{I \\ Title II, Equal Protection, and the Doctrine of State Sovereign IMMUNITY}

\section{A. Title II of the Americans with Disabilities Act}

Signed into law by President George H.W. Bush in 1990, the ADA sprung from detailed findings that the nearly forty-three million people with disabilities then living in America suffered from pervasive discrimination and social isolation..$^{40} \mathrm{~A}$ quantum step in the level of legal protection afforded to the disabled, ${ }^{41}$ the ADA applies to discrimination both by states

37. Hason v. Med. Bd., 279 F.3d 1167 (9th Cir. 2002), cert. granted, 123 S. Ct. 561 (2002), cert. dismissed, 71 U.S.L.W. 3639 (U.S. Apr. 3, 2003).

38. See Garrett, 531 U.S. at 374 n.9.

39. 532 U.S. $598(2001)$.

40. See 42 U.S.C. $\$ 12101$ (2000) (Equal Opportunity for Individuals with Disabilities: Findings and Purpose); Timothy M. Cook, The Americans with Disabilities Act: The Move to Integration, 64 TEMP. L. REv. 393, 393-95 (1991) (noting that the historical findings behind the Act were based on no less than eleven House hearings, three Senate hearings, sixty-three public forums around the country, and extensive correspondence between national disability rights advocates and federal and state elected officials).

41. The ADA's protections were modeled closely after the Rehabilitation Act of 1973, which generally prohibited recipients of federal funds from discriminating against persons with disabilities, yet its protections are much broader. Because the ADA covers states, private actors, and the federal government, and because its protections are of a highly specific nature, disability advocates and legal 
and their agents or instrumentalities ${ }^{42}$ and by private actors. ${ }^{43}$ In passing the Act, Congress targeted two primary forms of discrimination: (1) overt prejudicial conduct by the able-bodied toward the disabled, particularly toward those with obvious physical disabilities; and (2) the failure of public and private entities to remove physical and structural barriers that prevent people with disabilities from fully participating in society. ${ }^{44}$

Title II primarily addresses this second, more passive, form of discrimination. ${ }^{45}$ Title II, in particular, exercises a broad and comprehensive reach, providing the disabled with a federal right of action to redress discrimination by state and municipal governments and their agents. ${ }^{46}$ It states:

Subject to the provisions of this subchapter, no qualified individual with a disability shall, by reason of such disability, be excluded from participation in or be denied the benefits of the services, programs, or activities of a public entity, or be subjected to discrimination by any such entity. ${ }^{47}$

Thus, Title II enables those who can show that they are a "qualified individual with a disability" 48 to vindicate their rights in myriad contexts,

scholars have characterized this important law as the seminal legal protection for the disabled. See Rehabilitation Act of 1973, Pub. L. No. 93-112, 87 Stat. 394 (codified as amended at 29 U.S.C. $\$ 794(a)(2000)$ ). The Rehabilitation Act stated that no qualified person with a disability shall "solely by reason of her or his disability, be excluded from the participation in, be denied the benefits of, or be subjected to discrimination under any program or activity receiving Federal financial assistance." Id. See also Bonnie P. Tucker, The Americans with Disabilities Act of 1990: An Overview, 22 N.M. L. Rev. 13, 16 n.7 (1992) (lamenting the limited reach of the Rehabilitation Act of 1973, which did not cover private actors, and pointing out the practical need for the far broader legal regime provided by the ADA).

42. See 42 U.S.C. $\$ 12131$ (2000). The term "public entity" in Title 11 is defined as: "(A) any State or local government; (B) any department, agency, speeial purpose distriet, or other instrumentality of a State or States or local government." Id.

43. Title I's employment provisions cover employers "engaged in an industry affecting commerce who has 15 or more employees" as well as labor organizations and employment agencies. See id. § I21I1(4)-(7). Title III, for its part, requires privately owned or operated "public accommodations" (including, among other things, museums, gyms, inns, motels, restaurants, and schools) to provide equal access. See id. $\$ \S 12181-12189$. The main provision, contained in section 12182, states: "No individual shall be discriminated against on the basis of disability in the full and equal enjoyment of the goods, services, facilities, privileges, advantages, or accommodations of any place of public accommodation by any person who owns, leases (or leases to), or operates a place of public accommodation." Id. § $12 \mathrm{I} 82$.

44. Id. $\$ 12101(\mathrm{a})(5)(2000)$.

45. See H.R. ReP. No. 101-485 (Part 2), at 29-30, 4 I (I990).

46. See supra note 42 .

47. 42 U.S.C. $\$ 12132(2000)$.

48. The "Definitions" seetion of the ADA, 42 U.S.C. $\S 12131$ (2000) describes a "qualified individual with a disability" as:

an individual with a disability who, with or without reasonable modifications to rules, policies, or practices, the removal of architectural, communication, or transportation barriers, or the provision of auxiliary aids and services, meets the essential eligibility requirements for the receipt of services or the participation in programs or activities provided by a public entity. 
mainly those involving physical and programmatic access. Applications for the law include: obtaining physical access to vital public facilities, such as bureaucratic headquarters and polling places; ${ }^{49}$ protecting equal educational opportunities via provision of interpreter services and other accommodations; ${ }^{50}$ securing accessible transportation; ${ }^{51}$ and preventing inappropriate institutionalization in nursing homes when less restrictive care is available. ${ }^{52}$

Where people with disabilities are excluded from programs or physical facilities, Title II offers a panoply of remedies. The enforcement section of Title II (section 12133) incorporates by reference the remedies of section 794a of the Rehabilitation Act, which, in turn, incorporates by reference the remedies contained in Title VI of the Civil Rights Act of $1964 .^{53}$

\section{Id. $\$ 1231$.}

49. See 28 C.F.R. $\S 35.150$ (a) (2001). The U.S. Department of Justice's regulations implementing Title 11 provide that "[a] public entity shall operate each service, program, or activity so that the service, program, or activity, when viewed in its entirety, is readily accessible to and usable by individuals with disabilities." $I d$. Subsection (3) makes clear, however, that the right is not unlimited: public entities arc not required to make the change if it, "would result in a fundamental alteration in the nature of a service, program, or activity or in undue financial and administrative burdens." Id. $\$ 35.150$ (a)(3). But see Martin v. City of Los Angeles, 209 Cal. Rptr. 301 (Cal. Ct. App. 1984) (holding that a physically inaccessible police station did not run afoul of ADA because the law enforcement program, viewed in its entirety, was accessible).

50. See Siddiqi v. Regents of Univ. of Cal., No. C 99-0790 \$1, 2000 WL 33190435 (N.D. Cal. Sept. 6, 2000) (granting certification for class action brought under Title 11 by hcaring-impaired students challenging denial of vital services to disabled students at the University of California, Davis, and the University of California, Berkeley). Alleged violations included ineffective interpreter serviees and failure to provide note taking on a timely basis. See id. at *1-*3.

51. 42 U.S.C. $\$ \S 12141-12165$ (2000). Part B of Title II contains broad transportation standards and scctions 12143(b), 12149, and 12164 direct the Secretary of Transportation to promulgate implementing regulations.

52. See Olmstead v. L.C. ex rel Zimring, 527 U.S. 581 (I999) (holding that institutionalization of mentally disabled women when less restrictive care was available violated Title 11 , despite the state's "undue hardship" defense, under which the statc asserted that it lacked the financial resources to fund community-based care).

53. Understanding the remedies available under Title 11 is no easy task. Title 1l's "Enforcement" provision, 42 U.S.C. $\S 12133(2000)$, states that "[t]he remedies, procedures, and rights set forth in section 794a of Title 29 shall be the remedies, procedures, and rights this subchapter provides to any person alleging discrimination on the basis of disability in violation of scction 12132 of this title." Section 794a of the Rehabilitation Act of 1973, entitled "Remedies and attorneys fees," as relevant to Title 11, references the remedies contained in section $2000 \mathrm{~d}$ of Title Vl of the Civil Rights Act of 1964. See 29 U.S.C. $\$ 794 a(a)(2)(2000)$. Title V1 did not cxplicitly include a remedies section as passed, although the Supreme Court subsequently found an implied right of action. See Alexander v. Sandoval, 532 U.S. 275, 279-280 (2001). In Sandoval, the Court held that Title VI contains an implied private right of action for injunctive relief or damages, deducing that sincc it had already held in Cannon $v$. University of Chicago, 441 U.S. 677 (1979), that such a right cxisted under Title IX of the Education Amendments of 1972, and since Title IX was patterned after Title VI, there must be such a right under Title V1. See Sandoval, 532 U.S. at 280 (discussing Cannon). Moreover, Justice Scalia's majority opinion in Sandoval emphasized that Congress ratificd Cannon's view that Title IX (and thus Title VI) contained a private right of action by passing the Rehabilitation Act Amendments of 1986 and explicitly crcating such a remcdy. See id. The Rehabilitation Act Ainendments inserted the following language into Title Vl: 
Courts have interpreted Title II's remedies as comprising compensatory damages, ${ }^{54}$ and several federal courts have held that punitive damages are also recoverable. ${ }^{55}$ The ADA explicitly permits a successful Title II plaintiff to recover the award of reasonable attorneys' fees. ${ }^{56}$

\section{B. The Source of Congressional Authority to Enact Antidiscrimination Laws: The Equal Protection Clause and Section 5 Enforcement Powers}

Congress's constitutional authority to enact legislation that, like the ADA, applies directly to the states derives from the Fourteenth Amendment. Section I of the Fourteenth Amendment provides: "No state shall ... deny to any person within its jurisdiction the equal protection of the laws." ${ }^{\prime 57}$ Section 5 of the Fourteenth Amendment endows Congress with the "power to enforce, by appropriate legislation, the provisions of this article." 58 The Supreme Court historically has granted Congress great latitude under Section 5 in imposing specific affirmative legal duties upon states and crafting positive rights ${ }^{59}$ in an effort to further the social and

In a suit against a State for a violation of a statute referred to in paragraph (1), remedies (including remedies both at law and in equity) are available for such a violation to the same extent as such remedies are available for such a violation in the suit against any public or private entity other than a State. 42 U.S.C. $\S 2000$ d-7(a)(2) (2000).

Section 2000d-7 was passed as part of the Rehabilitation Act Amendments of 1986, Publ. L. No. 99506, and not the Civil Rights Act of 1964, Pub. L. No. 88-352, 78 Stat. 252.

54. See discussion infra Part III.A; infra note 216.

55. See discussion infra Part III. See also Ruth Colker \& Adam Milani, The Post-Garrett World: Insufficient State Protection Against Disability Discrimination, 53 ALA. L. REv. 1075, 1105 n.95 (2002).

56. 42 U.S.C. $\$ 12205(2000)$.

In any action or administrative proceeding commenced pursuant to this chapter, the court or agency, in its discretion, may allow the prevailing party, other than the United States, a reasonable attorney's fce, including litigation expenses, and costs, and the United States shall be liable for the foregoing the same as a private individual.

Id.

57. U.S. CONST. amend. XIV, §1.

58. Id. $\$ 5$.

59. For in-depth discussions of positive rights, compare Frank 1. Michelman, Foreword: On Protecting the Poor Through the Fourteenth Amendment, 83 HaRv. L. Rev. 7 (1969) (proposing that the Equal Protection Clause be used to effectuate "minimum protection" for positive economie rights among the disenfranchised), with Frank B. Cross, The Error of Positive Rights, 48 UCLA L. Rev. 857, 923 (2001) (criticizing Congress's rolc in guarantceing ethcreal positive rights as opposed to securing purportcdly neutral textual protections such as the Fifth Amendment's Takings Clause). Cross wrote that "the case for positive rights implicitly presumes that judges are benevolent magicians, willing and able to wave a wand and thereby dispel the sad conditions of poverty." Cross, supra, at 923. The debatc over the legitimacy of positive rights rages on in the civil rights context. See, e.g., Bonnie Poitras Tucker, The ADA's Revolving Door: Inherent Flaws in the Civil Rights Paradigm, 62 Oнго ST. L.J. 335 (2001). Professor Bonnie Tucker defends the ADA's affirmative accommodation requirements while conceding that the ADA sharply deviates from the Civil Rights Act of 1964 's prcdominantly neutral protections. She notes that "[s]incc equal treatment of people with disabilities often leads to unequal results, different treatment is required to ensure equivalent results." Id. at 354. Professor Christine Jolls seized on the distinction between antidiscrimination and so-called "accommodation law" and argued that the line between Title VII and laws like the ADA may not be so clear where disparate impact is essentially an accommodation requirement and that other seemingly neutral requirements are 
political equality envisioned by the Framers of the Fourteenth Amendment. ${ }^{60} \mathrm{~A}$ sampling of the numerous positive social rights Congress has thus far suecessfully used Section 5 to effectuate would include the right of non-English-speaking citizens to be frce from state-erected linguistic barriers on their right to vote, ${ }^{61}$ the right of eligible employees to take unpaid leave for pregnancy, adoption, the care of a loved one, or to recover from a serious illness, ${ }^{62}$ and the right of ethnic minorities to be free from otherwise neutral hiring practices that nevertheless disproportionately impede their employment opportunities (although this right has been called into doubt according to some scholars). ${ }^{63}$ It is in this framework of freedom and autonomy to craft positive rights in order to flesh out the Fourteenth Amendment's vague promise of "equal protection under law" that Congress enacted the ADA.

Equal protection for the disabled extends only so far, however. ${ }^{64}$ The Court first addressed the issue of equal protection for the disabled in City

similar to accommodation. See Christine Jolls, Antidiscrimination and Accommodation, I15 Harv. L. Rev. 642 (2001).

60. The Court at first extended the Equal Protection Clause to protect only a narrow variant of civic or "political" equality. See Strauder v. West Virginia, 100 U.S. (10 Otto) 303 (1879) (holding that a state law excluding Blacks from jury servicc violated the Fourtccnth Amendinent). In Brown v. Board of Edication, 347 U.S. 483, 494-96 (1954), however, the Court interpreted Section 5 to legitimate national desegregation of public schools, thereafter embracing the broader objective of what the majority in Plessy v. Ferguson, 163 U.S. 537 (1896), derisively had ealled "social" equality.

61. See Katzenbach v. Morgan, 384 U.S. 641 (1966). In Morgan, the Court upheld section 4(e) of the VRA as valid Section 5 legislation even though this provision, which rendered illegal any stateenacted English literacy prerequisites for voting, seemed to go far beyond the Supreme Court's holding in Lassiter v. Northampton County Board of Elections, 360 U.S. 45, 53 (1959), that a North Carolina literacy requirement did not in all cases violate Section 1 of the Fourteenth Amendment. Morgan, 384 U.S. at $651-53$.

62. See 29 U.S.C. \& 2612 (a)(I)(D) (2000) (Family and Medical Leave Act ("FMLA") of 1993). The FMLA entitles eligible employees up to twelve weeks of unpaid leave within a twelve-month period under these circumstances. Of course, while the Ninth Circuit recently held that the FMLA is a valid cxercise of Congress's Section 5 power in Hibbs v. Department of Human Resources, 273 F.3d 844 (2001), cert. granted, 122 S. Ct. 2618 (2002), the Supreme Court granted eertiorari and heard arguments on whether the FMLA validly abrogated state sovereign immunity.

63. Title VII offers plaintiffs a "disparate impact" framework under which they may prove unlawful discrimination alongside the more traditional "disparate treatment" model. 42 U.S.C. $§ 2000 \mathrm{e}-$ $2(k)(I)(A)(1994)$ (Title VII). The Supreme Court has upheld disparate impact as a basis for liability even where the plaintiff is unable to prove diseriminatory intent. See Griggs v. Duke Power Co., 401 U.S. 424, 431 (1971) (holding that Title VIl prohibits not only overt or intentional discrimination but also practices that are "fair in form, but discriminatory in operation"). However, the Supreme Court's recent holding in Alexander v. Sandoval, 532 U.S. 275 (2001), that there is no implied private right of action to enforce disparate impact regulations enacted pursuant to Title Vl's ban on intentional discrimination by federal agencies, according to a recent article, "cast[s] doubt upon Congress's power under Section 5 of the Fourteenth Amendment to enact legislation ineorporating a disparate impact methodology, since that Amendment's substantive prohibition, like Title Vl's, has been found to reach only intentional discrimination." John Arthur Laufer, Alexander v. Sandoval and its Implications for Disparate lmpact Regimes, 102 Colum. L. Rev. 1613, 1613 (2002).

64. As the next Section will show, these limits affect any analysis of Congress's power to abrogate states' sovereign immunity. See infra Part I.C. 
of Cleburne v. Cleburne Living Center ${ }^{65}$ in which a proposed operator of a local center for the developmentally disabled brought a Fourteenth Amendment challenge to a municipal zoning ordinance that excluded such homes from certain districts. Although the Court ultimately found the zoning ordinance unconstitutional, it concluded that, because disability might be relevant to a host of government qualifications, the disabled were not a suspect class or quasi-suspect class. ${ }^{66}$ Consequently, disability classifications ${ }^{67}$ are entitled only to "rational basis" scrutiny ${ }^{68}$ which requires mercly that the state have some possible legitimate end for the designation. ${ }^{69}$ This holding rejected Justice Marshall's view that, due to a long history of social alienation and mistreatment, the developmentally disabled should be treated as a quasi-suspect class. ${ }^{70}$ Despite later debates as to whether Cleburne in fact properly applied rational basis review or some stricter permutation thereof (also known as "rational basis review with bite"), ${ }^{71}$ a

65. 473 U.S. 432 (1985).

66. Id. at 442-43. By comparison, classifications based upon race, alienage, or national origin, which generally have no connection to any legitimate state objectives, are subject to "strict" scrutiny and can only be sustained if they are neeessary for a so-called "compelling state interest." See, e.g., Brown v. Bd. of Educ. of Topeka, Shawnee County, 347 U.S. 483, 495 (1954). Similarly, classifieations based on gender or illegitimacy, which trigger "intermediate scrutiny," have little connection to legitimate state objectives and, under the seminal case of Craig v. Boren, 429 U.S. 190 (1976), must be struck down unless the classification has a "substantial rclationship" to an "important governmental interest." See also Trimble v. Gordon, 430 U.S. 762, 767 (1977) (holding that legislation targeting illegitimate children is subject to intermediate scrutiny). Women and illegitimates therefore constitute "quasi-suspect" classes because they have historically becn subjected to invidious discrimination, albeit to a lesser degree than racial minorities such as African Amcricans. For more discussions of the varying levcls of constitutional scrutiny, see ERwIN Chemerinsky, Constitutional Law: Principles and Policies 527-538 (1997).

67. Classification is largely an intuitive concept that has received little jurisprudential discussion. Onc recent article notes that therc is not a clcar answer to the question since few of the Supreme Court opinions provide in-depth discussion of what the term "classification" means. Daniel Nussbaum, The Craziest Reform of Them All: A Critical Analysis of the Constitutional Implications of "Abolishing" the Insanity Defense, 87 CoRnell. L. REv. 1509, 1542 n. 187 (2002). He notes, however, that all laws classify: "Every time an agency of government formulates a rule-in particular, every time a legislature enacts a law-it classifies." Id. (quoting Miehael Perry, Modern Equal Protection: A Conceptualization and Appraisal, 79 CoLUM. L. REv. 1023, 1068 (1979)).

68. There was no clear majority in Cleburne, with Justice White authoring the lead plurality opinion and Justice Stevens penning a separate concurrence joined by Chief Justice Burger. While agreeing with the majority's view that the zoning law at hand lacked a rational basis, the concurrence questioned the utility of the three traditional levels of scrutiny. Cleburne, 473 U.S. at 45 I (Burger, C.J., concurring). Justice Marshall's dissent, in contrast, emphasized that the Court did not really apply rational basis scrutiny since "Cleburne's ordinance would surely be valid under the traditional rational basis test." Id. at 456 (Marshall, J., dissenting).

69. "The general rule is that legislation is presumed to be valid and will be sustained if the classification drawn by the statute is rationally related to a legitimate state interest." $1 d$. at 440 (citing Schweiker v. Wilson, 450 U.S. 221, 230 (1981)).

70. Id. at 460-63 (Marshall, J., dissenting) (noting that the mentally retarded have been subjected to a history "of segregation and discrimination that can only be called grotesque").

71. Although Cleburne clearly stands for the proposition that the disabled are a non-suspect class and disability discrimination claims are subject only to "rational basis" review, the decision created great confusion since the Court appeared to ignore its own rule by aetively searching the record to 
clear majority in Heller v. Doe $e^{72}$ affirmed that rational basis review applied to all state disability classifications, which must be upheld under Section 1 of the Fourteenth Amendment so long as any "conceivable state of facts" supports them. ${ }^{73}$

\section{The Rehnquist Court's Use of State Sovereign Immunity as a Limit on Antidiscrimination Law}

Despite the broad enforcement powers historically granted to Congress under Section 5, the Supreme Court has used state sovereign immunity as a mechanism to limit the liability that Congress may impose on the states through civil rights laws such as the ADA. The Eleventh Amendment states that the "judicial power of the United States" does not extend to "any suit in law or equity, commenced or prosecuted against one of the United States by Citizens of another State, or by Citizens or Subjects of any Foreign State." "74 Under a strict textual reading, the Eleventh Amendment relieves states only of the burden of defending against suits brought by citizens of other states. ${ }^{75}$ Since the 1890 decision in Hans $v$. Louisiana ${ }^{76}$ however, the Supreme Court has treated the amendment as a limit on federal question jurisdiction even when the suits are brought by a state's own citizens. More recently, state sovereign immunity has been treated as a structural, rather than textual, "inherent principle" that limits the ability of citizens to bring private suits in their own state courts based on federal causes of action. ${ }^{77}$ By seizing on the doctrine of state sovereign

determine whether the city's claimed rational bases (that is, concern ovcr the negative attitudes and fcars of residents who would live close to the home for the mentally retardcd and safcty interests related to the number of inhabitants in the home) were legitimate. See id. at 437 . By concluding, via searching judicial review that these reasons were not rational, the majority led Justice Marshall to comment in his dissent that "the ordinance surely would be valid under the traditional rational-basis test." Id. (Marshall, J., dissenting in part and concurring in part). This review has been alternatively called "active rational basis review" and "rational basis review with bite." See Note, Rational Basis Review with Bite: Intermediate Scrutiny by Any Other Name, 62 IND. L.J. 779 (1987).

72. 509 U.S. 312,320 (1993).

73. Id. (citing FCC v. Beach Comm., 508 U.S. 307, 313 (1993)).

74. U.S. Const. amend. Xl.

75. Id. Note that the Supreme Court has interpreted this amendment to cover suits brought by citizens against their own state. See Kimel v. Florida Bd. of Regents, 528 U.S. 62, $72-73$ (2000). The amendment is rooted in the Framers' deep concern for federalism. See ThE FEDERALiST No. 81 , at 487 (Alexander Hamilton) (Clinton Rossiter ed., 1961) ("It is inherent in the nature of sovereignty not to be amenable to the suit of an individual without its consent.").

76. I34 U.S. I, 15 (1890) (rejecting a suit brought under federal question jurisdiction against a state by one of its citizens).

77. The Supreme Court in Alden v. Maine, 527 U.S. 706, 727-30 (1999), affirmed the dismissal on non-Eleventh Amendment sovereign immunity grounds of a suit brought in state court by several Maine probation officers against the State of Maine for back overtime compensation and compensatory damages under the federal Fair Labor Standards Act. Writing for the majority, Justice Kennedy rejected the notion that state sovereign immunity is confined to the apparent limit contained in the Eleventh Amendment on Article III diversity jurisdiction over suits brought against states, stating that "the 
immunity ${ }^{78}$ the Rehnquist Court, has reshaped Fourteenth Amendment jurisprudence to severely hamper Congress's power to hold states accountable under antidiscrimination laws such as the ADA.

\section{Abrogating State Sovereign Immunity}

The Supreme Court has established standards by which Congress may abrogate that immunity. In 1989, the Court in Pennsylvania v. Union Gas Co. held that Congress could abrogate state sovereign immunity under either the Commerce Clause or Section 5 of the Fourteenth Amendment, thereby subjecting states to liability, concomitant with its power to fashion certain federal rights. ${ }^{79}$ However, after Justice Thomas replaced Justice Marshall, the Court retreated from this position in 1995, ruling in Seminole Tribe of Florida v. Florida that Congress could abrogate sovereign immunity via Section 5, but not via the Commerce Clause, because it prcdated the Eleventh Amendment. ${ }^{80}$ Now joined by Justice Thomas, the former Union Gas dissenters elevated sovereign immunity to a "background principle" that extends beyond the text of the Eleventh Amendment. ${ }^{81}$ In order to validly abrogate state sovereign immunity, Congress must satisfy two requirements. The preliminary requirement is purely formalistic. Congress first must make an "unmistakably clear" 82 statement of its intent to abrograte. ${ }^{83}$ Second, Congress may only abrogate state sovereign immunity pursuant to an express constitutional grant of authority (that is, in this

States' immunity from suit is a fundamental aspect of sovereignty which the States enjoyed before the ratification of the constitution, and which they retain today." $I d$. at 713 .

78. State sovereign immunity has animated the Supreme Court's jurisprudence for the last halfdecade. See Fed. Maritime Comm. v. So. Carolina Ports Authority, 535 U.S. 743 (2002); Kimel, 528 U.S. at 120; Alden, 527 U.S. at 706; City of Boerne v. Flores, 521 U.S. 507 (1997); Seminolc Tribe of Florida v. Florida, 517 U.S. 44 (1996). Federal Maritime, the most recent of the sovereign immunity cases, held that sovereign immunity shields states from private claims before federal administrative tribunals, which Justice Thomas considered roughly similar to Article Ill adjudications. See Federal Maritime, 535 U.S. at $1874-75$.

79. 491 U.S. $1,20(1989)$.

80. Seminole Tribe, 517 U.S. at 59-60.

81. Id. at 72. In response, Justice Souter penned a ninety-two-page dissent in whieh he reiterated Ninth Circuit Judge William A. Fletcher's point that the Eleventh Amendment never was intended to do more than limit diversity jurisdiction in cases wherc a state was the defendant and certainly was not intended to limit federal question jurisdiction. Id. at 50 (citing William A. Fletcher, A Historical Interpretation of the Eleventh Amendment: A Narrow Construction of an Affirmative Grant of Jurisdiction Rather than Prohibition Against Jurisdiction, 35 Stan. L. Rev. 1033 (1983)).

82. Id. at 56 (quoting Dellmuth v. Muth, 491 U.S. 223, 227-28 (1989)).

83. For example, in Title V of the ADA, Congress made such a "plain statement" where the statute reads:

A State shall not be immune under the eleventh amendment to the Constitution of the United States from an action in Federal or State court of competent jurisdiction for a violation of this chapter. In any action against a State for a violation of the requirements of this chapter, remedies (including remedies both at law and in equity) are available for such a violation to the same extent as such remedies are available for such a violation in an action against any public or private entity other than a State.

42 U.S.C. $\S 12202(2000)$. 
case pursuant to Section 5 of the Fourteenth Amendment) ${ }^{84}$ In its 1999 Kimel v. Florida Board of Regents decision, ${ }^{85}$ the Court held that the question of whether Congress has acted pursuant to a valid constitutional grant of power depends upon whether the law at issue satisfies the so-called "congruence and proportionality" test for valid Section 5 legislation first articulated in City of Boerne v. Flores. ${ }^{86}$

Under Boerne, a statute is a valid exercise of Congress's Section 5 abrogation power only if the law is congruent with and proportional to the unconstitutional conduct it seeks to prevent or remedy. ${ }^{87}$ Looking to past voting rights cases, Justice Kennedy urged in his majority opinion in Boerne that Congress's Section 5 power is fundamentally remedial rather than substantive, ${ }^{88}$ and Congress therefore only has the power to "'enforce' not the power to determine what constitutes a constitutional violation." 89 The "congruence and proportionality" test requires a reviewing court to identify (1) whether there is a historical pattern of unconstitutional wrongs that Congress sought to remedy through the statute at issue, and (2) whether the corrective means set forth is proportional to the remedial goal..$^{90}$

By relying on the Boerne standard as the test for proper abrogation, the federal judiciary assumed strict control over equal protection law, giving federal courts virtual de novo review of all congressional equal protection enactments that purport to abrogate state sovereign immunity. This is so because the judiciary, via judicial review, retains the last word on the Fourteenth Amendment's true meaning due to its ability to interpret Section 1's reach. Turning away from the deferential rational-basis-type review of congressional enactments represented in Katzenbach $v$. Morgan $^{91}$ - in which the Court upheld a provision of the VRA of 1965 (another piece of Section 5 legislation) that outlawed English-only state voting laws even though this went beyond the Court's own earlier interpretation of Section 1 as not per se outlawing English-only state voting requirements-courts now require that Congress tailor its laws narrowly to police the Court's own conception of what equal protection means.

84. See Seminole Tribe, 517 U.S. at 59.

85. 528 U.S. $62(2000)$.

86. 521 U.S. 507 (1997). It should be noted that Boerne was not itself an Eleventh Amendment immunity case, but rather involved the narrower question of when Section 5 legislation might exceed Congress's authority by creating a zone of substantive protections that exceed Section 1 of the Fourteenth Amendment.

87. Id. at $518-20$.

88. Id. at 519 (citing South Carolina v. Katzenbach, 383 U.S. 301, 325-26 (1966)).

89. Id.

90. Id. at 520 .

91. 384 U.S. 641 (1966). 
As many prominent scholars have pointed out, ${ }^{92}$ the Boerne standard for valid abrogation of sovereign immunity adopted in Kimel is inconsistent with the judiciary's historically deferential approach to antidiscrimination laws. For purposes of this Comment, it suffices to say that "congruencc and proportionality" is without precedent as a standard for abrogation of sovereign immunity. In the past, the Court had always deferred to antidiscrimination legislation (whether enacted under Section 5 or the Commerce Clause) so long as it bore some loose rational relationship ${ }^{93}$ to important national social policy goals, for example, the same way that the creation of a national bank in McCulloch loosely related to Article I's express grant of Congress's power to regulate commerce among the several states. ${ }^{94}$

\section{a. The Congruence Requirement}

This first prong of the congruence and proportionality analysis requires the court to review the legislative history of the law under review to determine (1) whether there is a clear pattern and practice of discrimination by states, ${ }^{95}$ and (2) whether that discrimination is unconstitutional under the level of protection granted by Section 1 of the Fourteenth Amendment. ${ }^{96}$ The Supreme Court, in its two principle equal protection cases involving the disabled, Cleburne $e^{97}$ and Heller, ${ }^{98}$ articulated a standard, (which I here refer to as the "Cleburne-Heller" standard) by which state discrimination against the disabled must be judged. It held that such state discrimination is not unconstitutional (that is, it does not violate Section l's protections) if it can be supported by any rational basis. Thus, the Cleburne-Heller standard serves as the yardstick for whether Section 5 legislation is in fact properly tailored to remedy truly unconstitutional discrimination. The result is that Congress may not subject states to liability for their discriminatory actions even where there is a clear pattern and

92. See, e.g., Evan H. Caminker, "Appropriate" Means-Ends Constraints on Section 5 Powers, 53 STAN. L. REV. 1127 (2001) (criticizing the congruence and proportionality inquiry into Section 5 enactments as fundamentally inconsistent with the looser "rational relationship" test applied in the context of Article 1 powers in McCulloch v. Maryland, 17 U.S. (4 Wheat.) 316 (1819). Professor Caminker argues that the Court has failed to adequately justify its especially harsh scrutiny of Section 5 law, stating that "the Court nowhere explains in Boerne and its progeny why policing the proper boundaries of power requires a much stricter means-ends tailoring in the Section 5 context." Id. at 1187. See also Steven A. Engel, The McCulloch Theory of the Fourteenth Amendment: City of Boerne v. Flores and the Original Understanding of Section 5, 109 Y ALE L.J. 115 (1999).

93. See, e.g., Katzenbach, 384 U.S. 641.

94. See McCulloch v, Maryland, 17 U.S. (4 Wheat.) 316, 389 (1819); supra note 21.

95. Such as there had been in paradigmatic civil rights cases like Heart of Atlanta Motel, Inc. $v$. United States, 379 U.S. 241 (1964), and Katzenbach v. McClung, 379 U.S. 294 (1964). See also infra note 153.

96. See supra Part 1.B.

97. City of Cleburne v. Cleburne Living Ctr., 473 U.S. 432 (1985).

98. Heller v. Doe, 509 U.S. 312 (1993). 
practice of discrimination against the disabled, if the bulk of this discrimination would have been justified (that is, could have been constitutional) under the Court's rational basis review. ${ }^{99}$

For example, at issue in Boerne was Congress's use of its Section 5 powers to protect certain forms of religious expression that it viewed as fundamental under the First Amendment, ${ }^{100}$ even though the Supreme Court in a prior case had explicitly held such expression unprotected by the text of the amendment itself. ${ }^{101}$ The majority, led by Justice Kennedy, clarified that, although Congress can enact remedial legislation to flesh out the protections implicit in Section 1 of the Fourteenth Amendment, ${ }^{102}$ it has no power to alter the substantive dimensions of this protection, ${ }^{103}$ especially where the Court already has defined those substantive boundaries. According to the Court, such quasi-judicial power would result in a usurpation of the Court's ultimate power to interpret the law. ${ }^{104}$ In essence, Congress had sought to extend constitutional protection beyond the limits clearly set by the Court in case law. ${ }^{105}$

\section{b. The Proportionality Requirement}

Should "proportionality" be viewed as a distinct inquiry from "congruence"? The Boerne Court speaks obliquely of "congruence and proportionality" as describing the appropriatc nexus between the "injury to be prevented or remedied and the means adopted to that end." 106 The role of proportionality is confusing because the initial analysis of whether the legislation is designed to prevent unconstitutional discrimination by its nature seems, as a practical matter, to require courts to simultaneously look to the remedial burdens that a given statute imposes upon states. Remember that in the "congruence" analysis, the question of whether legislation is bolstered by a history of unconstitutional discrimination is a means to an

99. See supra Part I.B; see also Heller, 509 U.S. 312.

100. The statute at issue in Boerne was the Religious Freedom Restoration Act of 1993, 42 U.S.C. $\S \S 2000 \mathrm{bb}-2000 \mathrm{bb} 4$ (1994).

I01. See Dep't of Human Res. of Oregon v. Smith, 494 U.S. 872, 880 (I990) (holding that "neutral, generally applicable... law[s]" are exempt from constitutional scrutiny even where they prohibit or substantially burden religious exercise).

102. Id.

103. See City of Boerne v. Flores, 521 U.S. 507, 519 (1997).

104. The Boerne majority rcferenced Justice Marshall's famous statement from Marbury v. Madison that "[i]t is emphatically the province and duty of the judicial department to say what the law is." Boerne 521 U.S. at 536 (citing Marbury v. Madison, 5 U.S. (1 Cranch) 137, 177 (I 803)). The Court in Boerne minimized the impact of the congruence and proportionality analysis it articulated by stating that, "[I]egislation which dcters or remedies constitutional violations can fall within the sweep of Congress' enforcement power even if in the process it prohibits conduet which is not itself unconstitutional." Id. at 518 .

105. Post and Siegel have eriticizcd sharply this new approach as diminishing Congress's traditional role in helping the Supreme Court shape the substantive dimensions of equal protection. Post \& Siegel, supra note 22 .

106. See Boerne, 521 U.S. at 508. 
end and not an end unto itself. To answer the essential question of whether the legislation was designed to "remedy" such unconstitutional discrimination seems to require an inquiry into remedies even before we ask the clear "proportionality" question of whether remedies are narrowly tailored to the goal of weeding out discrimination. That Title II burdens states by requiring them to provide accommodations to persons with disabilities whenever such accommodations would not cause fundamental alteration of a given service or program or cause an undue financial burden seems relevant to both the kind of discrimination Congress sought to remedy and whether it acted proportionately: 107

So, are "congruence" and "proportionality" overlapping portions of a mushy abrogation test or, rather, distinct analytical steps of a neatly divided inquiry? ${ }^{108}$ The Supreme Court has not yet answered the question. The semantic morass emerges when one considers how the initial inquiry into "congruence" in the case of Title II (after we remember that under Cleburne the disabled are only protected under Section 1 from irrational discrimination by states) seemingly can lead only to the conclusion that its remedies are "substantive" because Congress is raising the level of Fourteenth Amendment protection to which the disabled are entitled (and therefore venturing out of their remedial role into an impermissible substantive one). Incongruousness would seem to stop the Boerne inquiry cold and eliminate any reasonable hope that proportionality can save the day if the law does not serve to remedy a kind of discrimination that the Supreme Court considers unconstitutional. The congruence analysis has shown already that the law is clearly "so out of proportion to a supposed remedial or preventive object that it cannot be understood as responsive to, or designed to prevent, unconstitutional behavior."109

Yet, even in those cases where the congruence inquiry suggests strongly that some piece of Section 5 law is substantive in nature, "proportionality" might be viewed as having two valuable nonduplicative aims: (I) setting parameters for further inquiry where the examination of the scope of unconstitutional conduct sought to be prevented by Congress does not necessarily implicate the congressional remedies imposed or lead to a conclusion that the Section 5 legislation is "substantive"; and (2) providing a judicial fail-safe by requiring lower courts to "check

107. For an explanation of "undue hardship" and "fundamental alteration" exceptions, see supra note 49 and infra note 135.

108. Cf. Caminker, supra note 14. Anothcr recent article notcs that the Court in Boerne failed to provide much guidance on the difference between congruence and proportionality as applied in the Section 5 review. J. Randy Beck, The Heart of Federalism: Pretext Review of Means-End Relationships, 36 U.C. DAvIs L. REv. 407 (2003). The author agrees with Caminker that "congruence" generally requires an inquiry into whether the legislation serves to further a legitimate constitutional objective and "proportionality" asks whether the means employed are excessive or not. $l d$. at 432 .

109. Boerne, 521 U.S. at 532. 
their work" and giving higher appellate courts another mechanism by which to determine whether lower courts have made a good-faith effort in deciding whether Congress has acted within its proper sphere of authority.

\section{Application of the Congruence and Proportionality Test to Title II by the Circuit Courts Pre-Garrett}

Prior to Garrett, most circuit courts faced with the question of whether Congress validly abrogated sovereign immunity in passing Title II applied the Boerne congruence and proportionality test and ruled that Congress's abrogation was defective. The central challenge for these courts was how to incorporate into their analyses the standard of rational basis review for discrimination against the disabled that was articulated in Cleburne and Heller. Not all of the circuits agreed on the best way to face this challenge. For example, reflecting the majority view, the Fourth and Eighth Circuits applied rational basis review to find that Title II imposed burdens on states far exceeding those needed to avoid irrational discrimination. In applying the congruence prong of the Boerne analysis, ${ }^{110}$ these courts employed rational basis review in considering whether there was a requisite pattern of unconstitutional discrimination by states prior to the ADA. As discussed in Part II, these analyses parallel the Supreme Court's reasoning with regard to Title I in Garrett, and therefore serve as important indicators of how the Court was likely to treat Title II in Hason. In contrast, the Ninth Circuit, which did not incorporate rational basis review into its congruence and proportionality analysis, held in Dare v. California that Title II did not exceed Congress's Section 5 powers. ${ }^{11}$ After discussing the Ninth Circuit's approach, I will turn to the Fourth and Eighth Circuit cases.

\section{The Ninth Circuit's Failure to Use Rational Basis Review}

In Dare, the State of California had appealed a district court's finding that the state's six-dollar parking placard fee charged to disabled drivers was illegal. ${ }^{12}$ The case involved the so-called "surcharge regulation," which prohibits states from passing on the costs of providing equal access (in their efforts to comply with Title II's integration mandate) solely to the disabled. ${ }^{113}$ In Dare, the court never even considered rational basis review

110. The Ninth Circuit in Dare defined the "congruence" analysis as "identification of the 'Fourteenth Amendment 'evil' or 'wrong' that Congress intended to remedy,' using historical experience as a reference point." Dare v. California, 191 F.3d 1167, 1174 (9th Cir. 1999) (quoting Fla. Prepaid Postsecondary Educ. Expense Bd. v. Coll. Sav. Bank, 527 U.S. 627, 639 (1999)). Caminker questions whether the Supreme Court ever intended that "congruence" and "proportionality" would have distinct analytic content, but, assuming they do, suggests that "congruence" roughly means "whether the measure actually prevents or remedies a sufficient quantity of identifiable constitutional violations or is instead too underinclusive." Caminker, supra note 14, at 1153-54.

111. Dare, 191 F.3d at 1175.

112. Id. at 1169 .

113. See 28 C.F.R. § 35.130(f) (2001). 
relevant to the question of whether Congress had successfully identified a pattern of historical discrimination against the disabled. The court blurred the line between what would constitute prohibited discrimination under Section $I$ and the threshold showing of such discrimination needed to support prophylactic legislation under Section 5, offering the legal conclusion that "[a]lthough disabled people do not constitute a suspect class, the Equal Protection Clause prohibits irrational and invidious discrimination against them." 114 According to the court, the legislative record reflected "specific factual findings of arbitrary and invidious discrimination against the disabled." 115

The court essentially parroted the definition of what would constitute discrimination under Section I (that discrimination would remain unlawful irrespective of Title Il's validity) followed by a broad unsubstantiated conclusion that the congressional record was replete with examples of such discrimination. While the court was correct that invidious or intentional discrimination would violatc Section 1 regardless of what level of scrutiny was applied, it failed to consider how much of the discrimination in the record actually was (or would likely have been found to be) unconstitutional. Professors Robert Post and Reva Seigel have emphasized how invidious classifications, as defined by the Supreme Court, are those created "'with an evil eye and an unequal hand' or motivated by 'a feeling of antipathy' against a specific group of residents." 116 The Dare majority never supports its view that the discrimination in the congressional record comported with this high standard required for a showing of discrimination under the Cleburne-Heller standard. The Ninth Circuit's conclusion that Congress found discrimination that, in retrospect, it would paint as "invidious" or "arbitrary" 117 is hardly tantamount to a showing that "there is reason to believe that many of the laws affected by the congressional enactment have a significant likelihood of being unconstitutional," 118 as required by Boerne.

The Dare majority also manipulated the meaning of Cleburne by using the Supreme Court's requirement of deference to state legislative classifications as a justification for abandoning rational basis review in deference to congressional antidiscrimination statutes like Title II. The Ninth Circuit claimed that the Supreme Court specified in Cleburne that "how this large and diversified group [of people with developmental disabilities] is to be treated under the law is a difficult and often a teehnical matter, very much a task for legislators guided by qualified professionals

\footnotetext{
114. Dare, 191 F.3d at 1174.

115. Id.

116. Post \& Siegel, supra note 22, at 463.

117. Dare, 191 F.3d at 1175.

118. City of Boerne v. Flores, 521 U.S. 507, 532 (1997).
} 
and not by the perhaps ill-informed opinions of the judiciary." 19 Yet the Cleburne Court was not concerned with the evil of judicial meddling in federal laws like the ADA. Rather, the Court was worried about the inappropriateness of judicial interference with rational state classifications such as the very parking placard fee at issue in Dare. By refusing to apply rational basis review to the conduct of states, the court engaged in precisely the type of judicial interference with state laws and regulations that Cleburne sought to deter. It is ironic that the court pretends that such deference would govern review of congressional legislation even as it purported to engage in the stricter Boerne scrutiny, which would not be necessary if McCulloch "rational basis"-type review were still appropriate. ${ }^{120}$

\section{The Fourth and Eighth Circuits' Use of Rational Basis Review}

In evaluating the validity of Title Il, the Fourth and Eighth Circuits took an approach nearly opposite the Ninth Circuit's. They incorporated rational basis review into their analysis, and, consequently, held Title II invalid. In Brown v. North Carolina Division of Motor Vehicles, ${ }^{121}$ which also dealt with a surcharge statute, the Fourth Circuit reflected on the validity of Title 11 of the ADA. Although the court ultimately dismissed the plaintiff's appeal on the limited unconstitutionality of the regulation ${ }^{122}$ without specifically ruling on the constitutionality of Title II, its view could not be clearer. ${ }^{123}$ While the court agreed with the Ninth Circuit that the disabled have suffered historically in this country, ${ }^{124}$ it nonetheless rejected the notion that Congress could redefine the substance of Fourteenth Amendment protections. In other words, Congress could not outlaw states' discriminatory conduct where that conduct was permissible under the rational basis standard of review mandated by Section 1 and Cleburne. Alluding to the same concerns expressed in Boerne, the Fourth Circuit admonished that "[i]n striking state legislation that is clearly rationally grounded, Congress sought to do what Cleburne said it may not doestablish a new suspect or quasi-suspect equal protection classification." 25 ln light of this reasoning, the court held, the parking placard fee assessed to

119. City of Cleburne v. Cleburne Living Cir., 473 U.S. 432, 442-43 (1985).

120. See supra note 21 (discussing $M c C$ Culloch rational basis review).

121. 166 F.3d 698 (4th Cir. 1999), cert. denied, 531 U.S. 1190 (2001).

122. Id. at $708 \mathrm{n} .10$ (stating that "[d]eciding this case on the basis of the constitutionality of 28 C.F.R. $\$ 35.130(\mathrm{f})$, we need not pass on 42 U.S.C. $\$ 12132$ itself').

123. See Muller v. Costello, 187 F.3d 298 (2d Cir. 1999). The court made clear that although Brown purported to deal only with the regulation at hand, the logic of the decision would broadly undermine the bulk of Title ll's affirmative obligations: "Though Brown's holding is relatively narrow, its reasoning seemingly would have invalidated any of the ADA's substantive provisions." Id. at 309 n.3.

124. Brown, 166 F.3d at 707 ("Congress did make substantial findings about many forms of discrimination against the disabled in American life.") (citing 42 U.S.C. \$12101(a)(2000)).

125. Id. at 708 . 
the disabled by North Carolina was not "motivated by animus toward the class" but, rather, was a "modest cost-recovery mechanism rationally employed to recoup the costs of programs aimed at assisting persons with disabilities." ${ }^{26}$ Because there was no evil, the state was immune to a suit for damages.

In Alsbrook v. City of Maumelle, perhaps the most widely cited precedent for the view that Title II exceeds Congress's Section 5 power, the Eighth Circuit aligned itself closely with the Brown eourt. ${ }^{27}$ In Alsbrook, the disabled plaintiff sued the eity and state, claiming that the 20/20 vision classification required for all law enforcement officer positions was illegal because it excluded people from participation in the publie program based solely on their disabilities. ${ }^{128}$ The plaintiff here could not meet the vision requirement due to amblyopia in his right eye. The majority found that the vision classification was rational under Cleburne because it was connected to a legitimate state end. ${ }^{129}$ Furthermore, the court found that Title II was substantive legislation that effectively raised the level of protection available to the disabled under the Fourteenth Amendment and that was unsupported by any comprehensive showing of irrational state behavior.

In its "congruence" analysis, like all the other courts that have addressed Title II's legislative record, the majority conceded that Congress had made detailed findings of pervasive diserimination against the disabled and agreed that deference was appropriate. ${ }^{130}$ Like Brown, the eourt focused primarily on the "proportionality" prong of the Boerne analysis. It emphasized that the burden shifting effectuated by Title II (that is, from Section I's burden on disabled plaintiffs to negate that any possible basis for the classification under Cleburne-Heller ${ }^{131}$ to a burden on the defendant to provide the requested Title II "reasonable accommodation" to policies and procedures unless it could prove that such applications would cause a "fundamental alteration" 132 or "undue financial and administrative burdens"133) transcends any conception of remedial legislation. ${ }^{134}$ The court stated that Title II "does far more than enforce the rational relationship

126. Id. at 707.

127. 184 F.3d 999 (8th Cir. 1999).

128. Id. at 1002 .

129. Id. at 1003 .

130. Id. at 1007 ("[W]e should defer to Congress's assessment of the problem.").

131. Heller v. Doe, 509 U.S. 312 (1993).

132. 28 C.F.R. $\S 35.130$ (b)(7) (2003) (stating that "[a] public entity shall make reasonable modifications in policies, practices, or procedures when the modifications are necessary to avoid discrimination on the basis of disability, unless the public entity can demonstrate that making the modifications would fundamentally alter the nature of the servicc, program or activity").

133. Id. $\S 35.164$ (Nondiscrimination on the Basis of Disability in State and Local Government Services).

134. See Alsbrook, 184 F.3d at 1009. 
standard recognized by the Supreme Court in Cleburne. Under Title II, a state's program, service, or activity, even if rationally related to a legitimate state interest and valid under Cleburne, would be struck down unless it provided 'reasonable modifications." 135 Moreover, the court emphasized that not only was the multitude of disability discrimination claims now available under Title II far in excess of what would be allowed under Cleburne, but that the new liability imposed on states was premised on a utopian view of state resources. Such an unrealistic view could have the unintended consequence of undermining states' legitimate efforts to create programs for the disabled, according to the court, which explained that " $\mathrm{Ti}$ tle II's provisions detract from [state flexibility in shaping remedial efforts and allocating limited resources] by preventing states from making decisions tailored to meet specific local needs and instead imposing upon them the amorphous requirement of providing reasonable modifications in every program, service, and activity they provide." 136

Both the Alsbrook and Brown courts devoted substantial energy to the proportionality analysis, unlike the Ninth Circuit in Dare. Rejecting the plaintiff's argument that detailed findings of historical discrimination

135. Id. (citing the "reasonable modification" duty of 42 U.S.C. $\S 12131(2)$ and the "undue hardship" exception of 28 C.F.R $\S 35.130(b)(7))$. Title II's rules require that public entities make "reasonable modifications in policies, practices, and procedures when the modifications are necessary to avoid discrimination on the basis of disability." Id. The only limit on this amorphous burden is that a public entity is not required to make changes that would cause an undue burden. This includes changes that "fundamentally alter the nature of a scrviee, program or entity", 28 C.F.R. $\S 35.130(b)(7)(2001)$, and changes that impose an "undue burden," meaning significant difficulty or expense, 42 U.S.C. $\S 12132(2000)$.

136. Alsbrook, 184 F.3d at 1009 . Basic principles of scarcity play such a central role in public policymaking that the Supreme Court repeatedly has avoided defining constitutional protections in ways that force the hands of states in allocating resources. This is best reflected in the Court's due process jurisprudenee as it pertains to enforcement decisions made by federal and state administrative agencies. For example, enforcement decisions by ageneies generally are treated as presumptively unreviewable unless there is a specific statute on point and even then are held to an "irrational" type standard. Compare Dunlop v. Bachowski, 421 U.S. 560, 572-73 (1975) (holding the Labor Secretary's decision not to challenge labor election via civil action not to be reversed unless "so irrational as to constitute the decision arbitrary and capricious"), with Adams v. Richardson, 480 F.2d 1159, 1164 (D.C. Cir. 1973) (holding that the D.C. District Court had jurisdiction over challenge by Black students and taxpayers to the U.S. Office of Civil Rights' failure to enforce Title VII of the Civil Rights Act of 1964, by failing to end segregation by public education institutions that received federal funds). In response to a class action brought by Black students against the Secretary of Health, Education and Welfare for failure of the Office of Civil Rights ("OCR") to enforce desegregation requirements under Title VI, 42 U.S.C. $\$ 2000$ d, D.C. District Court Judge John Pratt imposed a multitude of dcadlines on the OCR for negotiation of voluntary compliance agreements with some two hundred previously segregated school districts. See Adams v. Richardson, 356 F. Supp. 92, 100 (D.D.C. 1973); see also, Kenyon D. Bunch \& Grant B. Mindle, Judicial Activism and the Administration of Civil Rights Policy, 1993 B.Y.U. Enuc. \& L.J. 76, 98 (arguing that "[h]ad Judge Pratt endeavored to dictate OCR's enforcement policics and manage the allocation of its institutional resources, the novelty of Adams, its affront to the separation of powers, would have been obvious"). The decision ultimately resulted in a complex web of settlements followed by further litigation against the agency. The morass created by the judge's ovcrsight of the agency is described in Jeremy Rabkin, Captive of the Court: A Federal Agency in Receivership, REG., May-June 1984, at 16. 
against the disabled could justify the panoply of Title II remedies and render Section 5 legislation valid, the Alsbrook court urged: "it cannot be said that Title II identifies or counteracts particular state laws or specific state actions which violate the Constitution. Title II targets every state law, policy, or program." 137 Further, while the Eighth Circuit did not dispute the breadth of anecdotal evidence of mistreatment of the disabled generally, the court held that there was no record of equally copious state discrimination in programs and services, noting " $[\mathrm{w}] \mathrm{e}$ do not think that the legislative record of the ADA supports the proposition that most state programs and services discriminate arbitrarily against the disabled." 138

In Brown, the Fourth Circuit squarely rejected the Ninth Circuit's position (echoed by the government in Dare) that where the showing of past discrimination against the disabled reached a certain quantum, a shifting of burdens from the disabled plaintiff (who must prove irrational discrimination) to the state (which must now show undue hardship or fundamental alteration) would be a proportional remedy. ${ }^{139}$ Likewise, the court rebuffed in toto review of whether a statute is constitutional under Section 5..$^{140}$

In sum, the Eighth and Fifth Circuits both concluded that Title II, despite its record of irrational discrimination against the disabled, was defective because it was not really "remedial" legislation that was narrowly tailored to weed out such discrimination. Although the Ninth Circuit remained committed (obviously influenced by its confidence that Katzenbach $v$. Morgan and related voter rights era cases which had applied loose $\mathrm{McCulloch}$ review to uphold Section 5 enactments were reconcilable with Boerne) to the notion that Congress could go significantly further than the Supreme Court had previously ventured based on its own legislative findings that people with disabilities had been the victims of pervasive discrimination, ${ }^{141}$ this reasoning was soundly rejected in Garrett. Yet, in Garrett the Supreme Court not only ratified the "proportionality" analysis of the Fourth and Eighth Circuits, it also implied that their "congruence" analysis had not been strict enough.

137. Alsbrook, 184 F.3d at 1009.

138. Id.

139. Brown v. N.C. Div. of Motor Vehicles, 166 F.3d 698, 707 (4th Cir. 1999) (stating that "Congress can intrude on state prerogatives only when seeking to remedy or prevent particular constitutional violations").

140. Id. at 703-04.

141. Alsbrook, 184 F.3d at 1009. 


\section{GARRETT AND ITS IMPLICATIONS FOR TITLE II OF THE ADA}

\section{A. Introduction to Garrett}

Patricia Garrett, a registered nurse, took a ycar-long sabbatical from work to undergo medical treatments for breast cancer (including a lumpectomy, radiation treatment, and chemotherapy). ${ }^{142}$ Upon her return to work, the University of Alabama, Birmingham Hospital demoted her from her position as dircctor of Nursing Services to a lower-paying job. ${ }^{143} \mathrm{~A}$ second plaintiff, Milton Ash, workcd as a security officer with the Alabama Department of Youth Services. ${ }^{144}$ Due to chronic asthma and his doctor's recommendation that he avoid carbon monoxide and cigarette smoke, Ash requested the department to accommodate him by permitting him to alter his work duties. And after a diagnosis with sleep apnea, his doctor recommended reassignment to the daytime shift. ${ }^{145}$ The department denied his request. ${ }^{166}$ Each plaintiff brought claims for compensatory damages under both Title I and Title II of the ADA, arguing that the state instrumentalities had discriminated against them based on thcir disabilities. ${ }^{147}$

At the district court level, the State of Alabama successfully moved for summary judgment on the theory that Congress had failed to validly abrogate state sovereign immunity. The district court agreed that the legislation was not appropriately "remedial" since the Supreme Court had made it clear in Boerne that "Congress cannot stretch Section 5 and the Equal Protection Clause ... to force a state to provide allegedly equal treatment by guaranteeing special treatment or 'accommodation' for disabled persons." 148 On appeal, the Eleventh Circuit reversed the district court's order, holding that Congress need only manifest a clear intent to abrogate state sovcreign immunity in order to subject states to compensatory damages. ${ }^{149}$ Although the Eleventh Circuit discussed the impact of Boerne on the sovereign immunity analysis, the court ultimately came to the

\footnotetext{
142. Bd. of Trustees of Univ. of Ala v. Garrett, 531 U.S. 356, 362 (2001).

143. Id.

144. Ash's and Garrett's cases were consolidated.

145. Gurrett, 531 U.S. at 362.

146. Id.
}

147. The claims were brought under both provisions because the employer was a public entity and it was not clear at the time whether private actions against employers-even if they were private entities-should be brought under Title 1 or 11 . The Court, later in Garrett, expressly refused to address the question, id. at $360 \mathrm{n} . \mathrm{l}$, leaving a eireuit-split on this issue, compare Zimmerman v. Or. Dep't of Justice, 170 F.3d 1169, 1174 (9th Cir. 1999) (holding that employment claims cannot be brought against public entities under Title 1I), with Bledsoe v. Palm Beaeh County Soil \& Water Conservation Dist., 133 F.3d 816, 821 (1 1 th Cir. 1998) (holding that the legislative history is explicit that Title 11 provides an employment discrimination cause of action).

148. Garrett v. Bd. of Trs. of Univ. of Ala., 989 F. Supp. 1409, 1410 (N.D. Ala. I998), aff d in part, rev'd in part, 193 F.3d 1214 (1 Ith Cir. 1999), rev'd, 531 U.S. 356 (2001).

149. Garrett v. Univ. of Ala. Bd. of Trs., 193 F.3d 1214, 1216-17 (1 Ith Cir. 1999), rev'd, 531 U.S. $356(2001)$. 
conclusion that there was a historical pattern of discrimination reflected in the history of the ADA and the Rehabilitation Act (the ADA's predecessor). ${ }^{150}$ Since the disabled were eligible for protection under Section 1 and Cleburne, the court agreed with the Ninth Circuit that the ADA (Title I and Title II inclusive) was well within Congress's enforcement power. ${ }^{151}$

In a majority opinion written by Chief Justice Rehnquist, the Supreme Court reversed the Eleventh Circuit, holding that Congress had exceeded its authority in enacting Title I of the ADA in three fundamental ways. First, according to the Court, Congress had failed to prove that there had been a history and pattern of irrational discrimination by states in the employment context. ${ }^{152}$ Articulating a new, stricter version of the "congruence" analysis, as the dissent pointed out, the majority far exceeded anything in the Boerne precedent because it imposed strict evidentiary-type standards on the legislative record. Incident to this element of its holding, the Court said for the first time ever that evidence of unconstitutional discrimination by local or municipal governments no longer was relevant to whether there had been a sufficient level of unconstitutional discrimination by states in the abrogation analysis. This level of "proof" now required by the Court was unprecedented and bore no similarity to the kind of evidence that had been needed to sustain early discrimination laws like the Civil Rights Act of $1964 .{ }^{153}$ Anecdotal disparate treatment indicia, for example, could no longer serve as proof of irrational discrimination. ${ }^{154}$ Second, under Garrett, discrimination by employers would only be deemed "unconstitutional" for purposes of the "congruence" analysis if it would likely be so held in an adjudication. ${ }^{155}$ In other words, Congress no longer appears to have any latitude to determine, based on anecdotal evidence, whether certain types of discrimination are a social problem requiring abrogation. ${ }^{156}$ Eliminating any remaining hope that Cleburne entitled the

150. Id. at 1218 (discussing 42 U.S.C. $\$ 12101$ (b) and 29 U.S.C. $\$ 701(\mathrm{~b})(1)(\mathrm{f})$, the sections of the ADA and Rehabilitation Act, respectively, in which Congress concluded that people with disabilities had been the victims of pervasive social discrimination).

151. Id. ("Both the ADA and Rehabilitation Act therefore are within the scope of appropriate legislation under the Equal Protcction Clause as defined by the Supreme Court.").

152. Garrett, 531 U.S. at 368-69.

153. See Heart of Atlanta Motel, Inc. v. United States, 379 U.S. 241, 243 (1964) (noting that the legislative record was "replete with evidence of the burdens that discrimination by race or color places upon interstate commerce"). See also Katzenbach v. McClung, 379 U.S. 294, 299-301 (1964) (accepting Congress's view in passing the Civil Rights Act of 1964 -based upon largely anecdotal evidence (similar to that in the ADA) - that a history of pervasive discrimination against African Americans existed).

154. Garrett, 531 U.S. at 370-71.

155. Id. at 367-68.

156. Colker, in her continuing authoritative scholarship on the ADA, notes the inherent problems with the judiciary forcing it to act in a quasi-adjudicative manner:

Rather than perform as neutral gatherers of the facts, Congressional committees must become advocates, culling the almost limitless record of state conduct to focus on incidents and practices that have the greatest potential for establishing unconstitutional intent... [T]his 
disabled to rational basis review "with bite,"157 (under which the ADA's legislative record would garner greater deference), the Court reaffirmed Heller's stringent standard for irrational discrimination under Section 1, under which a disabled plaintiff must negate any possible justification for the classification at issue. Finally, referring to the "proportionality" prong of the Boerne test, the majority indicated that the affirmative accommodation requirements imposed on employers by the ADA far exceeded any measures needed to protect against irrational discrimination. ${ }^{158}$ According to the Court, Congress's accommodation rules essentially shifted the burden from the disabled employee, who must prove that there could be no explanation for disability classifications other than irrational diserimination, to the employer, who, under the ADA, must prove that accommodation was too oncrous.

\section{B. Garrett's Implicit Invalidation of Title II}

\section{The Supreme Court's Firm Endorsement of Rational Basis Review}

While purporting to address only the validity of Title I employment discrimination claims brought against publie entities, Garrett left no doubt that Title II of the ADA is invalid as well. ${ }^{159}$ The Court implicitly rejected the Ninth Circuit's approach and, instead, took the same analytical approach to Title 1 that led the Fourth and Eighth Circuits (and at the point the Supreme Court granted certiorari in Hason, every other circuit to address this part of the ADA) to hold Title II unconstitutional.

In applying rational basis review, the Court explicitly acknowledged that Cleburne must be factored into the Boerne analysis, noting that the first step in determining the "congruence" of Section 5 legislation is to look at "scope of the constitutional right" 160 protected under the legislation. The Court made clear that the right to bc free from disability

new role for Congress is troubling. Factfinding in the legislative arena differs in its procedures and objeetives from factfinding in the courts. Congress collects evidence and builds a record in an effort to consider broad policy issues and formulate appropriately general responses, not to adjudicate discrete matters of individual justice. Transforming this information-gathering process into a kind of judicial branch activity invites strategic behavior that diminishes Congress as a lawmaking body.

Colker \& Brudney, supra note 13, at 139-40.

157. See supra note 71.

158. Garrett, 531 U.S. at 372.

159. Judge O'Scannlain's dissenting opinion (joined by Judges Kozinski, Kleinfeld, and Nelson) to the Ninth Circuit's refusal to rehear Hason en banc is emphatic in its view that Title 11 cannot survive the analysis set forth in Garrett:

"It bears repeating: This decision cannot possibly be right. Because Hason all but invites a grant of ccrtiorari and revcrsal for putting us out of step with the Supreıne Court and creating a split with every other circuit to have considered the issue, 1 must dissent from the order denying en banc hearing." Hason v. Mcd. Bd. of Cal., 294 F.3d 1166, 1167 (2002) (citations omitted).

160. Garrett, 531 U.S. at 365. 
discrimination by states is simply the right to be protected from irrational treatment, noting that:

[T]he result of Cleburne is that States are not required by the Fourteenth Amendment to make special accommodations for the disabled, so long as their actions toward such individuals are rational. They could quite hardheadedly-and perhaps hardheartedly-hold to job-qualification requirements which do not make allowance for the disablcd. ${ }^{161}$

Similar to the Fourth and Eighth Circuits' rcasoning, the Supreme Court held that the "history and pattern" 162 of discrimination that must be disccrnable via the "congruence" inquiry is one of unconstitutional treatment by states, not one of general social alienation. Despite the purported breadth of congressional fact-finding incident to Title I of the ADA, the Court concluded that " $[t]$ he legislative record of the ADA ... simply fails to show that Congress did in fact identify a pattern of irrational state discrimination in employment against the disabled." 163 The majority distinguished the disparate treatment of people with disabilities in the legislative history of the ADA from the kind of repeated and systematic treatment of minorities by states that had led the Court to uphold the VRA as valid under Section 5. ${ }^{164}$

Chief Justice Rchnquist juxtaposcd the findings of the ADA with those of the VRA, finding the ADA's legislative record comparatively anemic. Harkening back to the Supreme Court's earlier ruling in South Carolina v. Katzenbach, a seminal civil rights case in which it upheld VRA as valid enforcement legislation under Section 2 of the Fifteenth Amendment (this is the "enforcement clause" of thc Fifteenth Amendment), the majority noted that "State officials, Congress found, routincly applied voting tests in order to exclude African-Americans from registcring to vote." 65 While careful to note that disparate impact evidence could not bc enough, by itsclf, to sustain Section 5 legislation targeting cven suspect classifications (like race or national origin-ethnicity), ${ }^{166}$ the court noted that the VRA, which was targeted at discrimination predominantly on the basis of race and national origin-ethnicity, was supported by a quitc powerful rccord of disparate treatment. Prior to the VRA's passage, in some statcs there had been an "otherwise inexplicable" $50 \%$ registration gap dividing White and Black voters. ${ }^{167}$

161. Id. at $367-68$.

162. Id. at 368 .

163. Id.

164. Id. at 373-74 (contrasting the ADA rccord from that of the VRA of 1965 and related cases).

165. Id. at 373 (citing South Carolina v. Katzenbach, 383 U.S. 301,312 (1966)).

166. Id. at 372-73 (quoting Washington v. Davis, 426 U.S. 229, 239 (1976)).

167. Id. 
The Court's nuanced rational basis review of the ADA's legislative record contradicts the Ninth Circuit's loose approach to the legislative record taken in Dare, in which the majority had reasoned that instances of state discrimination underlying Title II could be unconstitutional even if rational, given the poor historical treatment of the disabled. ${ }^{168}$ And it carefully distinguished the record behind the VRA from the record behind the ADA, undermining the Ninth Circuit's reliance on the Supreme Court's purportedly permissive approach to Section 5 enactments. ${ }^{169}$

In its own effort to reconcile the levcl of review mandated by Cleburne with Boerne's unforgiving congruence and proportionality analysis in a way that could legitimate Title II's broad remedies, the Dare majority relied heavily on Justice Kennedy's diselaimer in Boerne that Congress could use Section 5 to outlaw a "broader swath of conduct"170 than was expressly prohibited by Section 1. The Supreme Court in Garrett implicitly rejects the notion that this dicta from Boerne could be applied to sustain the myriad affirmative burdens imposed on states by Title $I,{ }^{171}$ which it viewed as disproportionate to the goal of eliminating irrational treatment of the disabled. ${ }^{172}$

Moreover, the accommodation requirements imposed on states by Title 11 are every bit as incongruous with the goal of preventing irrational diserimination as were the accommodation requirements imposed by Title I. These include the aforementioned surcharge regulation (which bars passing the cost of modifications to the disabled as opposed to the general population), "reasonable modification" requirement (which requires modification to policies, services, and facilities unless a state can demonstrate a fundamental alteration to a program or an undue financial or administrative burden), as well as other requirements such as persons receiving personal care obtain it in the "least restrictive setting" available. ${ }^{173}$

168. Dare v. California, 191 F.3d 1167, 1175 (9th Cir. 1999).

169. Id. The Ninth Circuit stated that "[a]lthough Title II's provisions may prohibit some State conduct which would pass muster under rational basis review, the Title's focus is on eliminating the discrimination outlined in the factual findings." $l d$. The Ninth Circuit evidently presumes (something the Rehnquist Court does not) that the anecdotal instances of discrimination in the legislative record, which it obliquely refers to as "the discrimination outlined in the factual findings" were irrational. Id. No legal analysis is offercd in support of this conclusion.

170. City of Boerne v. Florcs, 521 U.S. 507, 536 (1997).

171. See Garrett, 53! U.S. at 371-72. Chief Justice Rehnquist specifieally discusscd how the "unduc hardship" exceptions to the reasonable accommodation proviso of Title 1, 42 U.S.C. $\S \S 12112(\mathrm{~b})(5)(\mathrm{a}), 12112(5)(\mathrm{B}), 1211 \mathrm{I}(9)$, "far exeeds what is constitutionally required in that it makes unlawful a range of alternative responses that would be reasonable but would fall short of imposing an 'undue burden' upon the employer." Id.

172. Id. The majority stated that "[e]ven were it possible to squeeze out of these examples a pattern of unconstitutional discrimination by the States, the rights and remedies created by the ADA against the States would raise the same sort of concerns as to congruence and proportionality as were found in City of Boerne." Id. at 372.

173. Compare 42 U.S.C. $\S 12112$ (b)(5)(a) (2000), with 28 CFR $\S \S 35.130(b)(7)$ (requiring modifications in policies, practices, or procedures needed to avoid discrimination), 35.130(d) (requiring 
Finally, the concurrenee in Garrett reiterates Heller's strict conception of irrational discrimination endorsed by the Eighth and Fourth Circuits. ${ }^{174}$ The burden on disabled equal protection claimants under Section 1 is to negate any possible legitimate reason that a defendant might have for failing to make an accommodation. As Justice Kennedy, who claimed to believe that the ADA after Garrett still has continuing vitality, ${ }^{175}$ stated, "[ $\left.t\right]$ he failure of a State to revise policies now seen as incorrect under a new understanding of proper policy does not always constitute the purposeful and intentional action required to make out a violation of the Equal Protection Clause."176

\section{The Supreme Court's Scrutiny of the Legislative Record}

The Supreme Court's unprecedented review of the congressional findings accompanying the ADA implicates much more than Title l's employment protections, since both Title 1 and Title 11 are supported by the same legislative record. This strict review belies the majority's view that there is an insufficient pattern of unconstitutional discrimination by states in the record underlying the Act as a whole (and also provides the most plausible explanation for why certiorari was granted recently in Hason to consider Title ll's constitutionality). The Court in Garrett initially limited its inquiry to employment discrimination, stating that the reeord failed to "identify a pattern of irrational state discrimination in employment."177 Yet, since the legislative findings prefacing the Act are not categorized by title, it would be tough to cabin the review solely to employment discrimination, ${ }^{178}$ especially since the Court broadly posited that "the great majority of these incidents [of discrimination] do not deal with the activities of States."179 Thus, it is likely that any of the ADA's titles will fail the Supreme Court's Boerne analysis.

administration of services, programs and activities in the "Icast restrictive setting"), and 35.130(f) (2001) (prohibiting state surcharges for cxpenses incurred by programs for the disabled). See also Thompson v. Colorado, 258 F.3d 1241 (10th Cir. 2001) (discussing Title Il's reasonable accommodation rcquirements).

174. Alsbrook v. City of Maumelle, 184 F.3d 999, 1008-09 (8th Cir. 1999) (en banc) (same); Brown v. N.C. Div. of Motor Vehicles, I66 F.3d 698, 706-07 (4th Cir. 1999) (interpreting Cleburne to call for strict rational basis review similar to that called for in $\mathrm{Heller}$ ).

175. Garrett, 531 U.S. at 375 (Kennedy, J., concurring).

176. ld. Cf. Olmstead v. L.C. ex rel. Zimring, 527 U.S. 581 (1999).

177. Garrett, 531 U.S. at 368.

178. Of course, the Court does distinguish between Title I and Title II. Compare, for example, the statcment that "[i]t is telling, we think, that given these large numbers, Congress assembled only [half a dozen examplesl of unconstitutional state discrimination in cmployment against the disabled," $i d$. at 370 , with the concession that "[t]he overwhelming majority of these accounts pertain to alleged discrimination by the States in the provision of public services and public accommodations, which are areas addressed in Titles 11 and 111 of the ADA," id. at 371 n.7.

179. $\quad l d$. at 369 . 
Traditionally, the legislative record of discrimination that supported enactment of the ADA faced few challenges, as the conventional wisdom held that the fact-finding underlying the congressional record was beyond reproach. As one scholar wrote: "The factual basis for ADA Title II is ... quite clear. The constitutional ehallenges to ADA Title II have not questioned whether Congress engaged in sufficient fact finding before enacting the ADA." 180 However, an article by Professors Robert Schapiro and William Buzbee points out that Garrett inaugurates an unprecedented level of judieial scrutiny of the legislative record: "The Court had never held that a speeific kind of 'legislative record' was necessary to validate Congress' exercise of its constitutionally vested powers." ${ }^{181}$ Thus, a close parallel exists between Garrett and United States v. Morrison ${ }^{182}$ insofar as the legislation at issue in both of these antidiscrimination laws was bolstered by an unusually detailed legislative record. Few thought that Morrison would fall victim to the Supreme Court's criticism of United States $v$. Lopez ${ }^{183}$ that the legislative record had been too weak to support the Gun Free School Zones Act of $1990^{184}$ as valid commerce legislation. Similarly, few in the disability rights community at the time of the ADA's passage ever anticipated that it would be necessary to compile more evidence of discrimination for the law to pass muster as valid under Section $5 .^{185}$

The Court has construed evidence of discrimination so narrowly that it is hard to imagine how congressional findings underlying Title II could have been adequate. This is surely Garrett's legacy. First, as noted above, local discrimination no longer may be counted as evidence of irrational conduct by states, ${ }^{186}$ despite Justice Breyer's persuasive argument in his Garrett dissent that state and local governments are so similarly situated as to be virtually interdependent. ${ }^{187}$ Second, testimony that Congress has culled for policy deliberations from a third-party agency is no longer tantamount to "legislative findings" but rather is treated as mere "unexamined,

180. Ruth Colker, The Section Five Quagmire, 47 UCLA L. REv. 653, 696 (2000). See also Timothy M. Cook, The Americans with Disabilities Act: The Move to Integration, 64 TEMP. L. REV. 393 (1991) (discussing the legislative factfinding behind ADA).

181. Buzbee \& Schapiro, supra note 13, at 90.

182. 529 U.S. $598(2000)$.

183. 514 U.S. 549 (1995).

184. See supra note 10

185. Arlene Mayerson of DREDF, who played a leading role in drafting, strategizing over, and ultimately passing the ADA, told mc how advocates working on the ADA did not think of this issue in the terms in which it has been articulated since Garrett. While there was a major effort to index and chronicle instances of discrimination, no particular quantum of proof was viewed as necessary.

186. Garrett, 531 U.S. at 368-69; see supra Part II.A.

187. Garrett, 531 U.S. at 378 (Breyer, J., dissenting) (noting that "[l]ocal governments often work closely with, and under the supervision of, state officials, and in general, state and local government employers are similarly situated"). 
anecdotal" evidence. ${ }^{188}$ Third, even if testimonial evidence was credited as legislative findings, it would have to show irrational discrimination under the Cleburne-Heller standard, whereas the bulk of the evidence in the record goes to "adverse, disparate treatment by state officials." 189

Consider, for example, Justice Breyer's Appendix C, which he submitted to rebut the majority's claim of insufficient evidence. Of the three hundred total examples of discrimination by states that he pulled from the congressional record, ${ }^{190}$ including discrimination by both employers and public entities, most are ambiguous at best. The appendix mentioned that the "California Relay System failed to provide telephone access to other states for deaf people," be justified if the state had a legitimate fiscal reason for doing so. Other similar instances of purportcd discrimination also are difficult, a posteriori, to label irrational. For instance, the failure of Illinois state and local governments to provide telecommunications devices for the deaf, ${ }^{192}$ a California Department of Motor Vehicles regulation requiring doctors to report patients with seizure disorders so that the Department could revoke their licenses, ${ }^{193}$ and a Colorado school's failure to transfer a special education student to a regular classroom until she filed a lawsuit ${ }^{194}$ all might well have been based on rational grounds if challenged under Section 1 . Given the quality of congressional fact-finding on these matters (which seemed ample at the time, during which anecdotal evidence of discrimination had always been the norm), one could not possibly conclude in

188. Id. at 370 . The majority took issue with the idea that "legislative findings" should be read to include information that was not, at the time given, clearly intended for congressional policymaking, noting that "[ $t]$ hese accounts, moreover, wcre submitted not directly to Congress but to the Task Force on the Rights and Empowerment of Americans with Disabilities, which [itself] made no findings on thc subject of state discrimination in employment." $I d$. at 370-71.

Justice Breyer's dissent raised the important point that the Court was "[r]eviewing the congressional record as if it were an administrative agency record," as it imposed its own notions of what information should be properly credited in legislative fact-finding, apparently with a mind toward judicial evidentiary standards. Id. at 376 (Breyer, J., dissenting). Breycr noted that "a legislature is not a court of law. And Congress, unlike courts, must, and does, routinely draw gencral conclusions-for example, of likely motive or of likely relationship to legitimatc need-from anecdotal and opinionbased evidence of this kind." Id. at 379-80. The majority's arguments as to rational basis review notwithstanding, it is hard not to view Chief Justice Rehnquist's discrete objection to ancedotal evidence as both inappropriate and insincere. This seems to belie an opinion that representatives and senators ought to actively manage the collection of policymaking data to ensure its veracity rather than passively balancing information submitted by intercsted third parties (lobbyists for example) as it has routinely done, in crafting legislation. Such a standard arguably would alter the entire machinery of Washington lawmaking.

189. Id. at 370.

190. Id. at 379 (Breyer, J., dissenting).

191. Id. at 395 app. C.

192. Id. at 405 (Numbered item 00581 describes the failure of state and local govcrnments in Illinois to provide telecommunications dcvices to deaf persons.)

193. Id. at 398 (item 00262).

194. Id. (item 00281). 
retrospect that there was no "reasonably conceivable state of facts that could provide a rational basis" for these policies as required by Cleburne-Heller. ${ }^{195}$

Certainly, several examples of state discrimination referenced in Justice Breyer's appendix seemed more invidious (that is, inexcusably motivated by animus against the disabled) and seem rationally unsupportable. These included "inaccessible voting machines [in Delaware],"196 and the fact that a wheelchair user trying to hail a bus in Colorado was passed by five bus drivers, all of whom claimed that their "lifts were broken." 197 However, even if the exclusion of disabled citizens from voting in elections or riding local transit seems patently unfair (much like the exclusionary zoning in Cleburne ${ }^{198}$ ), these loose anecdotal accounts implicate the same problem raised by the other evidence in the record that seemed more likely to be supported by some rational basis. ${ }^{199}$

\section{The Fifth and Tenth Circuits' Garrett-Induced Reversals}

Finally, the Fifth and Tenth Circuits' recent reversals on Title II's validity after Garrett further support the argument that the Supreme Court will find Title 11 unconstitutional. ${ }^{200}$ For the sake of brevity, this Section addresses only the Fifth Circuit's decision. In Reickenbacker v. Foster, the Fifth Circuit broke ranks with the Ninth Circuit, holding that its earlier precedent, which had upheld Title 11 as valid, improperly applied the congruence analysis because it had failed to identify a pattern of irrational discrimination by states. ${ }^{201}$ Overruling its earlier decision upholding Title II (in which it emphasized Congress's careful tailoring of Title II's remedies to anecdotal evidence of feasibility ${ }^{202}$ ), the Fifth Circuit explained that "the opinion pointed to provisions of both Title 1 and Title II of the ADA, but did not lay them next to the baseline of what defines constitutional state action under the Fourteenth Amendment." 203

195. Heller v. Doe, 509 U.S. 3/2, 320 (1993).

196. Garrett, 531 U.S. at 399 app. C.

197. Id. at 398.

198. City of Cleburne v. Cleburne Living Ctr., Inc., 473 U.S. 432, 448 (1985).

199. See supra text accompanying notes $191-93$ (providing three examples).

200. See Thomson v. Colorado, 278 F.3d 1020, 1034 (10th Cir. 2001), cert. denied, 122 S. Ct. 1960 (2002); Reickenbacker v. Foster, 274 F.3d 974 (5th Cir. 2001). In Thomson, the Tenth Circuit held that Title 11 cxceeded Congress's Section 5 power, reasoning along with the Fourth and Eighth Circuits that there was no clear pattern of unconstitutional state discrimination against the disabled in the context of programs services and facilities, nor were Title II's remedies proportional to this goal. Thomson, 278 F.3d at 1034.

201. Reickenbacker, 274 F.3d at $983-84$.

202. Coolbaugh v. Louisiana, I36 F.3d 430 (5th Cir. 1998). In Coolbaugh, the paraplegic plaintiff was required to take a road test in his hand-controlled car upon seeking to obtain a Louisiana driver's license while his ablc-bodied wife was only required to pass an eye exam. Id. at 432 .

203. Reickenbacker, 274 F.3d at 980-81. 
The Fifth Circuit also held that it had wrongly analyzed the proportionality inquiry under Boerne by failing to balance the affirmative duties imposed on states by the ADA against the breadth of unconstitutional discrimination. "Coolbaugh engaged in no detailed discussion of the rights and remedies available under Title II .... Since the constitutional analysis now requires a greater level of specificity than employed in Coolbaugh, we are persuaded that it has been effectively overruled." ${ }^{204}$ The court then aligned itself with the Fourth and Eighth Circuits' position that the affirmative burden on states to show "undue hardship" or "fundamental alteration" completely changes the burden allocation set forth in Cleburne and cannot be viewed as proportionally targeting irrational discrimination. ${ }^{205}$ As of this writing, only the First, Third, and D.C. Circuits have yet to take a clear position on Title Il's validity. ${ }^{206}$

III

\section{Life After Unconstitutionality? Title II's Remedial Significance IN THE Post-GaRRETT Climate}

In a footnote in Garrett, Chief Justice Rehnquist opined that the unavailability of money damages to the disabled that results from Congress's failure to validly abrogate state sovereign immunity is not fatal to disability rights because courts can continue to enforce the ADA "in actions [by the United States] for money damages, as well as by private individuals in actions for injunctive relief under Ex parte Young,"207 Yet, many legal scholars claim that the availability of those two options does not sufficiently protect the civil rights of people with disabilities. According to Professor James Leonard, for example, "the availability of monetary relief is critical to fashioning a complete remedy for disability discrimination. Very often a plaintiff cannot be made whole by an order against a state agency to desist from a discriminatory practice." 208 The question remains how, after Garrett, people with disabilities will be able to ensure that they can have access to voting booths and hospitals, obtain vital adaptive technologies, or obtain needed transportation. In this Part, I explain why the

204. Id. at 981 .

205. Id at 983 .

206. See, e.g., Lavia v. Pa. Dept. of Corrections, 224 F.3d 190, 194 n.2 (3d Cir. 2000) ("We are ... unable to address whether Title Il of the ADA was a valid exercise of Congress' $\$ 5$ power."); Torres v. P.R. Tourism Co., 175 F.3d 1, $6 \mathrm{n} .7$ (1st Cir. 1999) (indicating that it would find a private damages remedy under Title 11 if presented with the question).

207. Bd. of Trustees of Univ. of Ala. v. Garrett, 531 U.S. 356, 374 n.9 (2001). Professor John C. Yoo also minimized the significance of Garrett by stating that "a lot of deeisions are incremental and at the margins. They are just insulating the states from paying money damages." David G. Savage, Bias Claims Get Same 5-4 Answer from Justices: No, L.A. Times, Apr. 29, 2001, at Al.

208. See James Leonard, A Damaged Remedy: Disability Discrimination Claims Against State Entities Under the Americans with Disabilities Act After Seminole Tribe and Flores, 41 ARIZ. L. Rev. 651,652 (1999). 
remedies that Chief Justice Rehnquist said will survive Garrett are inadequate. I explore how far the Ex parte Young damages regime really extends. In the process, I revisit precisely what Title II's remedies are and whether any surviving remedies have a chance of promoting voluntary compliance with the ADA's important blueprint for social and political integration.

\section{A. The Implausibility of Recovering Money Damages for Intentional Discrimination}

As noted earlier in this Comment, Title II's remedies are imported by reference from the Rchabilitation Act of $1973,{ }^{209}$ which adopted the same remedies available under Title VI of the Civil Rights Act of 1964, which had prohibited discrimination on the basis of disability by recipients of federal financial assistance. ${ }^{210}$ Title II's statutory language does not explicitly refer to any private money damage action and the Supreme Court has never expressly addressed whether Title II contains a money damages award. ${ }^{21}$ Yet, the Supreme Court's 2001 holding in Alexander v. Sandoval that Title VI of the Civil Rights Act of 1964 contains an implied private right of action for injunctive relief and money damages ${ }^{212}$ seems to remove any lingering doubt that Title II comprises a damages remedy.

Even prior to Sandoval, the Supreme Court's reasoning in Franklin $v$. Gwinett County Public Schools ${ }^{213}$ - that Title IX of the Civil Rights Act ${ }^{214}$ allowed compensatory relief in intentional discrimination cases despite the absence of express language in the statute to this effect ${ }^{215}$-led every circuit court that considered the question to hold that there is indeed a private

209. See supra note 53.

210. 42 U.S.C. $\$ 2000$ d (2000) ("No person in the United States shall, on the ground of race, color or national origin, be excluded from participation in, be denied the benefits of, or be subjected to discrimination under any program or activity receiving Federal financial assistance.").

211. See Leonard J. Augustine, Jr., Note: Disabling the Relationship Between Intentional Discrimination and Compensatory Damages Under Title II of the Americans with Disabilitics Act, 66 Geo. WASH. L. Rev. 592, 599-600 (1998).

212. 532 U.S. 275, 279-80 (2000). Justice Scalia's majority opinion in Sandoval emphasized how Congress's Rehabilitation Act Amendments of 1986-which explicitly created a private cause of action under Title VI-validated the Court's earlier analytic position in a Title IX casc that Title VI (on which Title $1 \mathrm{X}$ was modeled) contained a private damages remedy. Id. The Rehabilitation Act Amendments of 1986, Pub. L. No. 99-506, states:

In a suit against a State for a violation of a statute referred to in paragraph (1), remedies (including both remedies both at law and in equity) are available for such a violation to the same extent as such remedies are available for such a violation in the suit against any public or private entity other than a state.

42 U.S.C. § $2000 \mathrm{~d}-7$ (a)(2) (2000).

213. 503 U.S. 60 (1992).

214. 20 U.S.C. $\S \S 1681-1688(2000)$ (Title XI bans discrimination on the basis of sex in the educational context.).

215. The Franklin Court ruled that "absent clear direction to the contrary by Congress, the federal courts have the power to award any appropriate relief in a cognizable cause of action brought pursuant to a federal statute." Franklin, 503 U.S. at 70-71. 
damages remedy for intentional discrimination under Title II of the ADA or, alternatively, under the Rehabilitation Act upon which it is based ${ }^{216}$ As one lower court put it, "because of the relationship among Title IX, Title VI, and section 504 [of the Rehabilitation Act], the Supreme Court's determination that money damages are available under Title IX is dispositive of whether money damages are available under $\S 504 . " 217$ The court added that that "[n]early evcry court that has addressed this issue following Franklin has determined that compensatory damages are available under $\S 504 .{ }^{.218}$

Construed literally, Chief Justice Rehnquist's majority opinion says that money damage claims brought under Title II are categorically precluded due to Congress's failure to validly abrogate state sovereign immunity. ${ }^{219}$ But it is unclear whether money damages remain recoverable in cases of intentional discrimination. There have been only a handful of lower court cases addressing whether money damages can still be recovered under Title II, assuming abrogation was defective. In the only circuit opinion dealing with the issue, the Second Circuit held in Garcia $v$. S.U.N.Y. Health Sciences Center that although Title II is invalid Section 5 legislation, a plaintiff nevertheless may recover money damages if he shows that the conduct prohibited under the ADA was motivated by "discriminatory animus or ill will based on the plaintiff's disability." ${ }^{220}$ Garcia involved a challenge brought by a medical student

216. See, e.g., Ferguson v. City of Phoenix, 157 F.3d 668, 674-75 (9th Cir. 1998) (finding an implied private damages remedy for intentional discrimination in light of Franklin: "The holding of Franklin merely states that compensatory damages are available for intentional violations of Title IX. That holding is consistent with... our holding today that compensatory damages are not available under Title 11 or $\S 504$ absent a showing of diseriminatory intent"); Johnson v. City of Saline, 151 F.3d 564, 573-74 (6th Cir. 1998) (holding compensatory damages are available for intentional discrimination under Title Il "by extension from their availability under the Rehabilitation Act and Title Vl"); Jeremy H. v. Mount Lebanon Sch. Dist, 95 F.3d 272, 279 (3d Cir. 1996) (holding money damages recoverable for intentional discrimination under the ADA). See also Powers v. MJB Acquisition Corp., 184 F.3d 1147, 1152-53 (10th Cir. 1999) (same); W.B. v. Matula, 67 F.3d 484, 494 (3d Cir. 1995) (same); Rodgers v. Magnet Cove Public Sch., 34 F.3d 642, 645 (8th Cir. 1994) (same); Waldrop v. Southern Co. Serv., Inc., 24 F.3d I52, 156-57 (11 th Cir. 1994) (same); Pandazides v. Va. Bd. of Educ. 13 F.3d 823, 830-32 (4th Cir. 1994) (same); Wood v. Spring Hill Coll., 978 F.2d 1214, $1219-20$ (1 th Cir. 1992) (holding money damages available for intentional discrimination under the Rehabilitation Act's section 504).

217. DeLeo v. City of Stamford, 919 F. Supp. 70, 73 (D. Conn. 1995). The district court denied defendant's motion to strike the claim seeking compensatory and punitive damages under section 504 . The suit was brought after the plaintiff, an applicant to the police department, was rejeeted as a result of reading problems that stemmed from diagnosed dyslexia.

218. Id. at $73 \mathrm{n} .3$ (listing additional cases that have held private damages to be recoverable under section 504).

219. See Bd. of Trustees of Univ. of Ala. v. Garrett, 531 U.S. 356, 360 (2001). Chief Justice Rehnquist framed the impact of defective abrogation of sovereign immunity on Title I's remedies in the broadest terms, stating: "We decide here whether employees of the State of Alabama may recover money damages by reason of the State's failure to comply with the provisions of Title $1 \ldots$. We hold that such suits are barred by the Eleventh Amendment." $I d$.

220. 280 F.3d 98, 111 (2d. Cir. 2001). 
suffering from Attention Deficit Disorder who was dismissed after his inability to complete the first-year curriculum. The court held that a Title II plaintiff may employ either of the two prevailing methods of proving intent in Title VII individual disparate treatment cases-the McDonnell Douglas-Burdine "pretext" framework, ${ }^{221}$ or the Price Waterhouse $v$. Hopkins "mixed motive" framework ${ }^{222}$ - as both are designed to ferret out "injurious irrational prejudice." 223 The court departed from the "deliberate indifference" standard that it and other courts previously applied to intentional discrimination claims brought under the Rehabilitation Act and the ADA. ${ }^{224}$ Assuming this is a valid approach to damages, it could permit a plaintiff to raise an inference via circumstantial evidence that animus motivated the challenged state conduct. ${ }^{225}$ As the Second Circuit itself noted,

221. McDonnell Douglas Corp. v. Green, 411 U.S. 792, 802-05 (1973). This seminal case set forth the "pretext" (sometimes misnamed "burden shifting") approach, which governs the majority of individual disparate treatment claims brought under Title VII. Under this rubric, proof of intentional discrimination involves threc steps. First, the plaintiff must establish a prima facie case: (1) that she was in a protected class (here a qualified individual with a disability); (2) that she suffered an adverse action (here, presumably, failure to provide a given accommodation); and (3) that there was a causal ncxus between the protected trait of disability and the adverse action. Id. at 802 . Second, the defendant would have to produce a legitimate nondiscriminatory reason for the adverse action. $I d$. at 803-04. Third, the plaintiff would have an opportunity to show that the defendant's legitimate nondiscriminatory reason for the adverse employment action was not worthy of credence. 1 d. at 804-05. The companion case of Texas Department of Community Affairs v. Burdine clarified that the burden on the defendant at the second stage is merely one of production and the ultimate burden of persuasion remains with the plaintiff. 450 U.S. 248,256 (1981). As the Court put it in its description of the pretext phase: "The plaintiff retains the burden of persuasion. She now must have the opportunity to demonstrate that the proffered reason was not the true reason for the employment decision. This burden now merges with the ultimate burden of persuading the court that she has been the victim of intentional discrimination." $I d$.

222. 490 U.S. 228, 252-58 (1989). Price Waterhouse set forth the alternative "mixed motive" framework used in disparate impact cases in which there is strong circumstantial evidence of discriminatory animus. The "mixed motive" framework is far preferable to plaintiffs because in such cases the burden of persuasion (as opposed to the far lesser burden of production in McDonnell Douglas) shifts to the defendant, who can only avoid liability by "proving that it would have madc the same decision even if it had not allowed [the protectcd trait] to play such a role" in the employment decision. ld. at 244-45. Price Waterhouse involved the company's allegedly discriminatory failure to promote Ann Hopkins to partner despite her having landed a twenty-five million dollar contract with the U.S. Department of State and various other qualifications. The employer had rcmarked, among othcr things, that she was "nacho," "overcompensated for being a woman," and ought to take "a course at charm school." These comments serve as direct evidence of discrimination under the "mixed motive" framework. Id. at 255-56; see also infra note 225.

223. Garcia, 280 F.3d 98 at 112.

224. See id. at 115 (citing Bartlett v. N.Y. State Bd. of Law Examiners, 156 F.3d 321, 331 (2d Cir. 1980), Duvall v. County of Kitsap, 260 F.3d 1124, 1138-42 (9th Cir. 2001) (holding same "deliberate indifference" standard governed claims for intentional discrimination under the ADA).

225. Justice $O^{\prime}$ Connor set forth the clearest explanation of what would constitute sufficient evidence for a plaintiff to avail the "mixed motive" (as opposed to the McDonnell-Douglas "pretext") proof framework in her concurrence in Price Waterhouse. She loosely described it as evidence suggesting that a decision maker was motivated by illegitimate considerations with respect to a given decision. Price Waterhouse, 490 U.S. at 271 (O'Connor, J., coneurring). Of course, this is not true "direct evidence" in the legal sense, which, if believed, necessitates a certain legal conclusion. At least 
"both ... approaches will lessen a plaintiff's difficulty establishing animus relative to what would be demanded under rational basis review, which requires that a plaintiff disprove the existence of any legitimate government justification." 226 Indeed, both the "mixed motive" and pretext frameworks are a far cry from the standard for Section 1 liability for disability discrimination that the Supreme Court set forth in Heller v. Doe $e^{227}$ and reiterated in Garrett. ${ }^{228}$ Hence, it should come as no surprise that the Fifth Circuit has criticized the Second Circuit's approach to intentional discrimination as inconsistent with the Supreme Court's ruling in Garrett. ${ }^{229}$ As a constitutional matter, the quantum of proof that Garcia requires of nonsuspect disabled plaintiffs to show "irrational" or invidious discrimination, which would continue to violate Section 1 of the Fourteenth Amendment irrespective of the ADA's constitutionality, is below what the Supreme Court has indicated is necessary.

Assuming, however, that the Second Circuit in Garcia is not simply redefining the constitutional standard for invidious discrimination against the disabled by grafting the Title VII burden-shifting that has been applied to suspect and quasi-suspect classes (that is, race and gender) to a nonsuspect class (that is, disability), there are still significant practical problems with its approach. While the pretext and "mixed motive" frameworks are theoretically far easier to satisfy than the kind of rational basis standard articulated in Heller, as a practical matter, a plaintiff still will need some means to legitimately raise an inference of animus. Successfully pleading animus is a heavy burden. To see the challenge Title II plaintiffs face, we might apply the Garcia standard to the paradigmatic Title II lawsuit: one involving a state's failure to provide accessibility features. In a recent district court case, a disabled plaintiff alleged that State University of New York at Buffalo had intentionally discriminated against him and other students by failing to remove architectural barriers to access despite full awareness of the responsibility to do so under Title II and in disregard of the plaintiffs' repeated requests to do so. The court granted summary

one court has described this test as "direct or very good circumstantial evidence." Deneen v. Northwest Airlines, 132 F.3d 431, 436 (8th Cir. 1998).

226. Garcia, 280 F.2d at 112 .

227. 509 U.S. 312,320 (1993).

228. Bd. of Trs. of Univ. of Ala. v. Garrett, 531 U.S. 356, 367 (2001) (reiterating the strict rational basis standard from Heller).

229. The Fifth Circuit, in a footnote in Reikenbacker, noted its disagreement with Garcia. The court reasoned that if money damages are not recoverable because, as the Supreme Court held in Garrett, Title 11's accommodation-type remedies exceeded those necessary to protect against irrational discrimination, then the fact that a state's failure to provide accommodations was driven by animus would not change the situation. Reickenbacker v. Foster, 274 F.3d 974, 983 n.72 (5th Cir. 2001). The court stated: "The Garcia remedy suffers from the same defect that we have identified in Title 11, because the constitution imposes no such aecommodation obligation. Garcia's solution may be additionally flawed because, as we have noted, not all decisions governed by animus violate the Fourteenth Amendment." Id. 
judgment in favor the defendant because "knowing discrimination" or deliberate refusal to implement the law was not tantamount to irrational discriminatory animus or ill will under Garcia. ${ }^{230}$

Even if the plaintiff can show more than "knowing" or deliberate refusal to provide accommodations, this will still rarely, if ever, lead to liability for damages under either the pretext or "mixed motive" model. Under McDonnell Douglas, in order to establish a prima facie case, the plaintiff must affirmatively show some causal connection between the adverse action suffered (for example, in the Title II context, failure to provide some modification) and the protected trait (for example, a disability). ${ }^{231}$ Similarly, the Price Waterhouse model, as typically applied in the Title VII context, generally requires what Justice O'Connor in her concurrence in that case loosely called "direct evidence" of discriminatory animus (for example, statements made by a decision maker related to the decisionmaking process that reflect the presence of an impermissible discriminatory motive). ${ }^{232}$

According to the Second Circuit in Garcia, as long as the disabled plaintiff is able to plead, in good faith, facts that suggest discriminatory intent, ${ }^{233}$ such as a patently discriminatory comment made by a state official (or, in a "mixed motive" case, a discriminatory statement by a state official made in the course of the decision), the availability of money damages does not implicate Garrett's principle concern: that the ADA unfairly subjects states to sweeping financial liability for constitutional (that is, rational) discrimination. Of course, as noted above, there is a huge divide between the burden articulated in Heller and the far looser forms of proof required in the typical Title VIl case. This may explain why no other circuits have endorsed the Garcia opinion. ${ }^{234}$

230. Denmeade v. King, No. 00-CV-0407E(F) WL31018148 at *2 (W.D.N.Y. Aug. 1, 2002).

231. See McDonnell Douglas Corp. v. Green, 411 U.S. 792, 793 (1973).

232. See Price Waterhouse v. Hopkins, 490 U.S. 228, 277 (1989) (O'Connor, J., concurring).

233. Garcia v. S.U.N.Y. Health Scis. Ctr., 280 F.3d 98, 112 (2d Cir. 2001) (discussing how adoption of the "mixed motive" and pretext models of proof comport with the goal of limiting state liability for discrimination that is essentially rational). See also FED R. CIV. P. 11. Those who might suggest that disabled plaintiffs can now circumvent Garret by concocting facts that could lead to an inference of animus in an effort to shift burdens to the defendant ignore the requirement that the plaintiff swear the pleadings are true or face scvere penalties. Of course, much like those who decry "frivolous lawsuits" in the torts context, some might argue that so long as the legal system allows such burden-shifting for any plaintiff who is willing to perjure himself, it incentivizes dishoncsty and encourages disabled plaintiffs to lie.

234. Cf. Jennifer Lav, Conceptualizations of Disability and the Constitutionality of Remedial Schemes Under the Americans with Disabilities Act, 34 Colum. Hum. RTs. L. Rev. 197, 232 (2002) (arguing that the Garcia system of proof in Title 11 cases is in fact consistent with Garrett based on the Third Circuit's own assurances that the Garcia standard ferrets out discrimination based on animus). Yet the burden shifting effectuated under the Title Vll models of proof discussed in the text of this Comment clearly targets a wide swath of discrimination that might be upheld as rational under the striet model of proof imposed by Heller. 
Even if some intentional discrimination claims brought under Title II (those that are supported by proof of animus towards the disabled) are not barred by Garrett, it is still unlikely that such suits will provide much help to the vast majority of plaintiffs in the Title II context, given the difficulty of unearthing the kind of smoking-gun evidence necessary to raise an inference of animus. Moreover, in states where discrimination against the disabled goes unchecked, it seems quite unlikely that officials will make the kinds of comments, circulate the types of documents, or make the kinds of public remarks ${ }^{235}$ that probably would be required for a Title II litigant to overcome a motion for summary judgment. ${ }^{236}$ Further, Professor Ruth Colker's recent statistical analysis of ADA employment discrimination claims brought under Title I (which have always triggered the same pretext and "mixed motive" proof frameworks used in Title VII claims) showed that defendant-employers won $93 \%$ of ADA employment discrimination claims and $84 \%$ of appeals taken from those cases. ${ }^{237}$ Federal district court judges granted summary judgment virtually all of the time on the most clear-cut, benign factual questions, such as whether a plaintiff was a

235. Cf. 2 A. Larson \& L. Larson, Employment Discrimination $\S 50.10$ at 10-6 (1990) (stating that employers are "too sophistieated to profess their prejudices on paper or before witnesses").

236. The plight of average Title V11 plaintiffs at the summary judgment stage, under both the pretext and "mixed motive" models of proof, is well-documented. One article indicated that in a sixmonth period, fifty of fifty-three summary judgment grants in Title VII and Age Discrimination in Employment Act cases wcre affirmcd on appcal. See Ann C. McGinley, Credulous Courts and the Tortured Trilogy: The Improper Use of Summary Judgment in Title VII and ADEA Cases, 34 B.C. L. REv. 203, $229 \mathrm{n} .111$ (1993). The inability of most plaintiffs to get past a defense summary judgment motion in employment discrimination cases has been credited largely to the so-called "Cclotex Trilogy," a series of Supreme Court cases decided in the 1986 Term that significantly expanded the applicability of summary judgment under Federal Rule of Civil Procedure 56. In the principal case, Celotex v. Catrett, 477 U.S. 317 (1986), the Court held that the burden on the movant is merely to show that there is an "absence of evidence to support the nonmoving party's case." Id. at 325 . Thus, defendants are relieved of the traditional burden of production under which they were rcquired to affirmatively establish via evidence the absence of material issues of fact. Id. In Anderson v. Liberty Lobby, Inc., 477 U.S. 242 (1986), the Court converted the summary judgment burden into the same burden a plaintiff would have to meet to overcome a directed verdict after the presentation of his casein-chief. The plaintiff would need more than a "mere scintilla" of evidence, and the trial judge is required to make a calculated weighing of the plaintiff's evidence in ordcr to determine "whether reasonable jurors could find by a preponderance of the evidence that the plaintiff is entitled to a verdict." Id. at 251-52. Matsushita Elec. Indus. Co. v. Zenith Radio Corp. was an antitrust case in which the Court upheld summary judgment against the plaintiffs despite their unrebutted and unchallenged evidence supporting the existence of predatory pricing by Japanese television manufacturers. 475 U.S. 574, 587 (1986). Based solely on its sense from law and economics literature that predatory pricing was inefficient and therefore nonexistent, the Court found there to be no "genuine issue of material fact." Id. at 591. This decision, Justice White pointed out in his dissent, invited courts to go beyond the traditional inquiry into whether the plaintiff has met a burden of production and instead "decide whether the weight of the evidence favors the plaintiff." $1 d$. at 600 (White, J., dissenting). For more on the Celotex trilogy, see Samuel lsaacaroff \& George Lowenstein, Second Thoughts About Summary Judgment, 100 YALE L.J. 73 (1990) (commenting on how these decisions dramatically expanded the use of summary judgment as a substitute for trial on the merits).

237. See Ruth Colker, The Americans with Disabilities Act: A Windfall for Defendants, 34 Harv. C.R.-C.L. L. REv. 99, 100 n.10 (1999). 
qualified individual with a disability or whether a given accommodation was reasonable. ${ }^{238}$ Given the legal complexity of discriminatory intent (under either the pretext or "mixed motive" framework) and the high risk of prejudice, judges will not casually submit purported evidence of intentional discrimination to juries. More likely, claims of intentional discrimination by states will be met by even more hostility than other types of ADA claims.

Turning back to Title Il's underlying telos of political and social equality for America's disabled, it is hard to imagine how the availability of damage claims for intentional discrimination provides much consolation or softens the blow of Garrett. Even if the other circuits take the approach of the Second Circuit's Garcia decision, the disabled have reason to be disheartened where vindication of their social status hinges on such a high quantum of proof. To use an analogy, what if African Americans or Latinos who had been prevented from entering a state building or bathroom on the basis of their race were required to prove that the state intended to discriminate against them? Moreover, imagine that intentional discrimination could not be proven by evidence that the employer knowingly denied them access to the bathroom on racial grounds, but only by evidence that the employer somehow intended to injure them on racial grounds (that is, the employer had "ill will"). Clearly if this were the case equal protection law would be a laughingstock. Yet, suspect class or not, this is the very situation facing disabled plaintiffs, who, due to mobility or other impairments, are unable to use state bathrooms or other important facilities or programs ${ }^{239}$ Is there any doubt that such a high burden of proof fundamentally affirms the social and political inequality of people with disabilities?

\section{B. The Lack of Incentives for People with Disabilities to Pursue Injunctive Relief}

Chief Justice Rehnquist's insinuation that broad injunctive relief is still available under Ex parte Young, despite Title Il's defective abrogation of states' sovereign immunity, ${ }^{240}$ is equally hollow. Young mcrely held that state officials who act contrary to federal constitutional law may be sued for injunctive relief in their official capacities without implicating state sovereign immunity. The Young Court reasoned that individuals only would act in their official state capacity when that action was

238. See id. at 112-16 (1999). Cf. Van Detta \& Gallipeau, Judges and Juries: Why Are So Many Plaintiffs Losing Summary Judgment Motions and Would They Fare Better Before a Jury? A Response to Professor Colker, 19 REv. LITIG. 505 (2000) (arguing, alternatively, that poor lawyering has been the catalyst for summary judgment in the majority of cases).

239. See Emily Bazar, Disabled Still Left at the Door, SaCramento BeE, June 17, 2001, at Al.

240. Bd. of Trustees of Univ. of Ala. v. Garrett, 531 U.S. 356, 374 n.9 (2001). 
constitutional. ${ }^{241}$ Yct, Young permits only limited prospective injunctive relief under the moniker of equitable relief, and does not allow a plaintiff to avail retroactive remedies.

In Edelman v. Jordan, the Supreme Court clarified that suits against state officials under Young would not entitle a plaintiff to retrospective money awards merely because they might be labeled as equitable. ${ }^{242}$ In a class action suit brought against Illinois officials, the disabled sought equitable restitution for the failure of state administrators of the federal program, "Aid to the Aged, Blind or Disabled," to comply with strict time limits for grants. However, the Court squarely rejected the notion that a plaintiff could circumvent Young and recover money by raising a claim in equity, noting:

We do not read Ex parte Young... to indicate that any form of relief may be awarded against a state officer, no matter how closely it may in practice resemble a money judgment payable out of the state treasury, so long as the relief may be labeled 'equitable' in nature. ${ }^{243}$

Of course, Edelman's "bright line" rule treating prospeetive injunctive relief as available under Young where retrospective awards are not (on the theory that the latter is allowable but the former impermissibly burdens state treasuries) makes little sense when one considers that prospective injunctions may cost states far more than retrospective money awards. Justice Douglas made precisely this point in his dissent in Edelman. ${ }^{244}$ However, Chief Justice Rehnquist in Edelman did not seem to object to this irony, stating that "[s]uch an ancillary effect on the state treasury is a permissible and often an inevitable consequence of the principle announced in Ex parte Young., ${ }^{245}$ Where retrospective money awards come

241. 209 U.S. 123 (1908). Although the official is not acting under color of state authority for Eleventh Amendment purposes, it is still the state that is sued vicariously. See Home Tel. \& Tel. Co. v. City of Los Angeles, 227 U.S. 278, 285-86, 288 (1913). The "Ex parte Young fiction," as it is called, allows a suit against a state officer to go forward because he or she is sued in an individual capacity even though, as Professor Pam Karlan has noted, "it is only because the offieial is engaged in "state action' that therc is a constitutional violation in the first place." Pamela S. Karlan, The Irony of Immunity: The Eleventh Amendment, Irreparable Harm and Section 1983, 53 STAN. L. Rev. 1311, $1318(2001)$.

242. 415 U.S. 651 (1974). Even prior to Edelman, the Court clarified in Ford Motor Co. v. Deptartment of Treasury that if a private claim for equitable relief will result in payment from the state treasury, then the state was to be treated as the real party in interest and was entitled to invoke its sovereign immunity. Ford Motor Co. v. Dept. of Treasury, 323 U.S. 459, 464 (1945). The Court modified Ex parte Young, declaring that "when the action is in essence one for the recovery of money from the state, the state is the real, substantial party in interest and is entitled to invoke its sovereign immunity from suit even though individual officials are nominal defendants." Id.

243. Edelman, 415 U.S. at 666.

244. See id. at 683-84 (Douglas, J., dissenting) (noting that the retrospective award sought in the present case was far less than the cost of desegregating a school as required by a prospective injunction) (citing Griffin v. County Sch. Bd., 377 U.S. 218 (1964)).

245. Id. at 668 . 
impermissibly close to money damages, which are prohibited under the Eleventh Amendment, the costs of complying with a prospective injunction-according to Chief Justice Rehnquist—are ancillary.

The Young regime diminishes incentives for individual plaintiffs to litigate potential Title II claims. First, procedural burdens, such as the standing requirements for prospective injunctive relief under Young and the unavailability of jury trials, dampen incentives. Second, even if Title II plaintiffs overcome these obstacles, some courts have refused to allow them to bring these suits under Young, holding that they are not permitted under the ADA's remedial scheme. Finally, even assuming that these burdens are overcome, the unavailability of retrospective monetary awards and the slight chance of recovering attorneys' fees reduces incentives for disabled plaintiffs and their attorneys to invest time, energy, and money into risky lawsuits.

First, a Title II private plaintiff seeking prospective injunctive relief via Young faces several procedural disincentives. On the one hand, she faces a special burden of proving a substantial likelihood of being harmed by discrimination by the same entity in the future. ${ }^{246}$ On the other, she has no right to a jury trial. The Supreme Court has consistently held that there is no right to a jury trial under the Scventh Amendment for mere injunctive relief. ${ }^{247}$ The 1991 amendments to the Civil Rights Act (which apply to the ADA) explicitly state that a plaintiff only has a right to a jury trial if she seeks compensatory or punitivc damages. ${ }^{248}$ The historical justification for allowing only injunctive relief under Title II of the Civil Rights Act-that bench trials were preferable because juries at the time would be disinclined

246. See Los Angeles v. Lyons, 461 U.S. 95, 111 (1983) (holding that in order to enjoin the Los Angeles Police Department's use of choke holds, the plaintiff would have to prove a "substantial likelihood that he would again be wronged in a similar way"); Aikens v. St. Helena Hosp., 843 F. Supp. 1329 (N.D. Cal. 1994). The Northern District of California court held that the Lyons standing test governed ADA Titlc 111 claims. Professor Tucker has elaborated on how Aikens would prevent a significant number of Titlc 11 plaintiffs from challenging access barricrs. Tucker, supra note 59, at 37578. She cited one case, Proctor v. Prince St. George's Hospital, 32 F. Supp. 2d 830 (D. Md. 1998), in which a Title III plaintiff who was denied interpreters during discussions with the hospital regarding the need to amputate his left leg, was found to lack standing because he could not show that he was likely to return to the hospital in the future. Tucker, supra note 59.

247. See City of Monterey v. Del Monte Dunes, Ltd., 526 U.S. 687, 719 (1999) (citing Parsons v. Bedford, 28 U.S. (3 Pet.) 433, 447 (1830)). The Supremc Court stated in Parsons that jury trials were only required in suits where "legal rights were to be ascertained and determined, in contradistinction to those where equitable rights alone were recognized." Parsons, 28 U.S. at 447.

248. Civil Rights Act of 1991, 42 U.S.C. $\$ 1981$ A(b)(4)(c)(1)(1994). Sec also Project Life, Inc. v. Glendening, 139 F. Supp. 2d 703, 707 (2001) (holding no right to a jury trial in private ADA action unless damages are sought); Outlaw v. City of Dothan, No. 3 A.D. Cases 939, 8 A.D.D. 560, 5 NDLR P 333, 1993 WL 735802 at *7 (M.D. Ala. Apr. 27, 1993) (holding express right to a jury trial in Title I meant no such right existed under Title 11). Sec also Robert L. Strayer 11, Asserting the Seventh Amcndment: An Argument for the Right to a Jury Trial When Only Back Pay ls Sought Under the Americans with Disabilities Act, 52 VAND. L. REv. 795 (1999) (arguing that denial of a jury trial in equitable suits under the ADA violates the Seventh Amendment and encourages strategic plcading in conflict with policy underlying the Federal Rules of Civil Procedure). 
to punish racial discrimination-does not apply to discrimination on the basis of disability. Professor Colker's statistical research on the low probability of success in Title I employment claims indicates "that plaintiffs have so little chance of prevailing before judges at bench trials that it is hard to imagine that juries would present an even more sympathetic forum." 249 Or, the Title II plaintiff essentially faces the same burden at trial that she otherwise would have faced at the summary judgment stage ${ }^{250}$ and all questions of fact, such as whether an accommodation was reasonable, become questions of law for a judge.

Second, there are some circumstances in which injunctive relief under Young is simply unavailable as a matter of law. The Supreme Court has limited the availability of Young suits for injunctive relief where a statute comprises exclusive remedies under an "intricate remedial scheme." ${ }^{251}$ In Seminole Tribe, the Supreme Court held that a Young suit was not available to plaintiffs to enforce the Indian Gaming Regulatory Act ("IGRA") (by compelling the state governor to negotiate a gaming contract) where IGRA contained an exclusive remedial regime under which plaintiffs could obtain redress in federal courts. ${ }^{252}$ The majority emphasized that if it allowed Young suits to be used in lieu of 1GRA's specific remedies (which were no longer available in light of defective abrogation), it would be at cross-purposcs with Congress. ${ }^{253}$ Most courts continue to hold that Young relief remains available and that the ADA's remedies are not "exclusive," unlike IGRA. ${ }^{254}$ However, one fcderal district court has held that the ADA's remedies are exclusive, and thus, no such relief is permitted. ${ }^{255}$

249. Ruth Colker, ADA Title III: A Fragile Compromise, 21 Berkeley J. EmP. \& LaB. L. 377, 399 (2000) (citing supra note 234). As I noted above, her researeh indieated that $93 \%$ of Title I claims are won at trial and only $84 \%$ of those same claims are won on appeal. See supra tcxt accompanying note 237.

250. See supra notes $236-38$ and accompanying text.

251. Seminole Tribe of Florida v. Florida, 517 U.S. 44, 74 n. 17 (1996).

252. Id. IGRA's remedial scheme, contained in 25 U.S.C. \$ 2710 (d)(7), comprised several specific options for aggrieved parties. The Court emphasized, for example, where a federal distriet court found that a state had failed to negotiate in good faith, the only prescribed remedy was an order for the statc and Indian tribe to negotiate a compact within sixty days. Seminole, 517 U.S. at 74-75.

253. The Seminole Tribe majority also noted that a suit under Ex parte Young would "expose that official to the full remedial powers of a federal court, ineluding, presumably, contempt sanctions" and that "[i]f $\S 2710$ (d)(3) could be enforced in a suit under Ex parte Young, $\S 2710(\mathrm{~d})(7)$ would have been superfluous." Id. at 75 .

254. See, e.g., Koslow v. Pennsylvania, 302 F.3d 161, 179 (3d Cir. 2002) (citing Gibson v. Ark. Dept. of Corrcetions, 265 F.3d 718, 720-22 (8th Cir. 2001) (holding that ADA remedies are not exclusive under Seminole Tribe, and that IGRA is "markedly different")). The Eighth Circuit in Gibson noted that Congress, in crafting the ADA adopted existing eivil rights enforcement mechanisms available under the Civil Rights Act of 1964, and that Congress was awarc that federal courts had issued orders under the statute "eompelling state officials to perform their statutory obligations." Gibson, 265 F.3d at $72 \mathrm{I}$.

255. McGarry v. Director, Dep't of Revenue, State of Missouri, No. 19 NDLR P 81, 1999 WL 33204561 at ${ }^{*}$ (W.D. Mo. Dec. 9, 1999). 
Additionally, a few circuit opinions contradict Chief Justice Rehnquist's claim that Young suits can be used to enforce Title II, holding that Title II's statutory remedies apply to "public entities" only and not officers or state agents. ${ }^{256}$ The Seventh Circuit, in Walker v. Snyder, dismissed a suit brought against a state officer under Title II because "a suit based on Young is a suit against state officers as individuals, not against the state itself. We held ... that the only proper defendant in a action [sic] under the provisions of the ADA at issue is the public body as an entity."257 The court pointed out that Congress only prohibited discrimination by a "public entity" in section $12 \mathrm{I} 3 \mathrm{I}$ of Title 11, hence officers were not proper defendants. ${ }^{258}$ The Eighth Circuit, prior to Walker v. Snyder, held in Alsbrook that "Title II provides disabled individuals redress for discrimination by a public entity ... that term, as it is defined within the statute, does not include individuals." 259

In sum, a plaintiff who is content with a bench trial on the merits, who can show a likelihood of repeated future discrimination by the state, and who filcs her Title II claim in the right jurisdiction, may potentially recover prospective injunctive relief against officers or agents of the state. Theoretically, even if the costs to the state of complying with the injunction were extremely high, the plaintiff could force a state to provide access, for example, to a state building, by bringing the suit against the appropriate state official, such as the director of the department of corrections or the state highway agency. Assuming that a rational state will be induced to obey the court's order so as to avoid contempt charges and additional costs, Titlc II litigants in theory are capable of forcing states to comply with the federal law. This framework, however, is ill-suited to generate voluntary compliance for several additional reasons.

First, the unavailability of retrospective money awards minimizes the likelihood that potential Title II plaintiffs will pursue their claims. ${ }^{260}$ An architect of the ADA, Senator Tom Harkin, noted that "without the existence of damages as a remedy, you would not get widespread voluntary

256. Walker v. Snyder, 213 F.3d 344, 347 (7th Cir. 2000); see also Emerson v. Thiel Coll., 296 F.3d 184, 189 (3d. Cir. 2002) (holding, similarly, that no individual liability exists under Title 111, which covers owners, operators, and persons who lease or lease to others, places of "public accommodation").

257. See Walker, 213 F.3d at 347.

258. Id. at 346 .

259. Alsbrook v. City of Maumelle, 184 F.3d 999, 1005 (8th Cir. 1999) (en banc)

260. See Tucker, supra note 59, at 370-71 (arguing that money damages are vital to Title II enforcement). Tueker states that "[b]ecause there are no penalties imposed if an entity waits to comply with the law until such time as the plaintiff prevails in court, it is to the plaintiffs advantage to do exactly that." Id. at 374. She urges that although Congress clearly intended for plaintiffs to have to prove intentional discrimination under Title I of the ADA and Title VII of the Civil Rights Act of 1964 to avail money damages, it never did so in the case of Title II. Id. at 373-74. She states that "Congress chose not to extend those limitations to eases arising under ADA Title Il." Id. at 373. 
compliance or negotiated settlements, short of litigation."261 The heavy burdens and risks of enforcement fall almost entirely on the disabled themselves. While the U.S. Department of Justice may still pursue claims on behalf of people with disabilities, recent legal scholarship has pointed out the complete ineffectiveness of federal government agencies in vindicating disability rights in the far narrower context of employment alone. ${ }^{262}$ Popular opinion seems to be that ADA lawsuits have become so rampant that the law should be amended, ${ }^{263}$ but the plain truth is that few disabled individuals have the time, energy, or resources to pursue the numerous Title II claims that must be filed if every state polling place, hospital, educational facility, or office building is to be made accessible under a regime of prospective injunctive relief. ${ }^{264}$

Furthermore, a significant segment of the more than fifty-four million disabled Americans who are the victims of the political and social exclusion that Title II was meant to eliminate are barely capable of vindicating their own rights. Take, for example, the so-called "least restrictive setting" regulation (at issue in the well known case of Imstead $^{265}$ ), which requires that people with disabilities receive care in the "most integrated setting

261. Hearings Before the Comm. on Labor and Human Resources and the Subcomm. of the Handicapped on S. 933, 101st Cong. 209 (1989).

262. See Kathryn Moss et al., Unfunded Mandate: An Empirical Study of the Implementation of the Americans with Disabilities Act by the Equal Employment Opportunity Commission, 50 U. KAN. L. REv. 1 (2001). The authors, presenting the results of the broadest empirical study yet undertaken of ADA enforcement efforts, noted with regard to Title 1 enforcement that "Congress has never given the EEOC the resources the Agency needed to ensure an appropriate investigation of each case brought before it." $/ d$. at 3 . The authors also noted that just over $12 \%$ of the some 250,000 Title 1 claims pursued between the effective date of the Act and September 2000 yiclded benefits for the plaintiffs. ld. at 2, 4. See also Leonard, supra note 208, at 665 (noting that the federal government "does not have the resources to participate in a significant number of cases") (citing Joanre Brant, The Ascent of Sovereignty, 83 lowa L. REv. 767, 858 (1998)).

263. See, e.g., Loophole Lets Lawyers Sue over Dubious Problems, USA Today, Mar. 3, 2000, at A14 (describing an alleged national explosion of ADA lawsuits against private businesses by aggressive disability lawyers and the need for federal amendment to the ADA that would impose a ninety-day grace period on Title 111 lawsuits, and opining that "[t]he Batelaans [small business owners who are themselves disabled] were caught in a blizzard of nearly 600 federal lawsuits slapped on south Florida businesses by a handful of lawyers in recent months. In California, two lawyers filed 230 suits on behalf of one client"). At the time, 1 sought to address the concerns raised in the USA Today piece in a separate opinion-editorial. See Matt Taggart, Legislation Would Undermine the Rights of the Disabled to Have Full Access, L.A. Times, May 29, 2000, at B7.

264. A 2000 survey by the National Organization on Disability conducted by the Harris Poll found that people with disabilities are far more likely to live in poverty (with incomes below $\$ 15,000)(29 \%$ compared to $10 \%$ among able-bodied). See National Organization on Disability, The 2000 N.O.D./Harris Survey of Americans with Disabilities, available at www.nod.org/hs $2000 / \mathrm{html}$. In 1998, mean income for people with disabilities aged twenty-five to sixty-four was $\$ 20,422$ compared to $\$ 35,221$ for the able-bodied, including public benefits. See Joseph Dalaker, U.S. Census Bureau, Current Population Reports, Series P60-207, Poverty in the United States (Sept. 1999).

265. Olmstead v. L.C. ex rel. Zimring, 527 U.S. 581 (1999) (holding that the State of Georgia failed to comply with this regulation by placing two developmentally disabled women in a segregated institutional environment based on its unsupported claim that alternative placement would pose an undue financial burden). 
appropriate to the needs of qualified individuals with disabilities." ${ }^{266}$ Clearly, those cognitively disabled or mentally ill individuals who are the victims of inappropriate institutionalization ${ }^{267}$ are also the least likely to go out and sue for pyrrhic injunctive awards under these Title II regulations. Most of them are in nursing homes for the precise reason that they are unable to care for themselves.

Unless public interest lawyers with organizations like the Disability Rights Education and Defense Fund ("DREDF") or Disability Rights Advocates seek out these individuals and agree to bear the initial costs of bringing a lawsuit on their behalf, their civil rights likely will not be enforced. If money damages were available, this might draw a pool of quality legal talent willing to endure the long and costly process of suing states. Without money damages, it seems that only the most altruistic attorneys will be willing to take on such cases. Moreover, even the most altruistic attorneys are highly unlikely to take Title II suits given that statutory attorneys' fees are not reliable. The Supreme Court held in Buckhannon Board and Care Home, Inc. v. West Virginia Department of Health and Human Resources that attorneys' fees are not available under the ADA when the lawsuit merely acts as a catalyst for voluntary compliance. ${ }^{268}$ Since the attorneys' fees statute provides that they are only available to a "prevailing party," ${ }^{269}$ this excludes circumstances where either the state cures the access defect after the suit has been filed or the plaintiff, who controls the litigation, chooses to settle the claim.

Prior to Buckhannon, virtually all circuit courts treated an ADA litigant who generated voluntary complianee as a "prevailing party" theory that even if they never obtained a final judgment on the merits, the lawsuit, as thc Suprcme Court put it, "brought about a favorable change in

266. 28 C.F.R. $\$ 35.130$ (d) (2003).

267. See, e.g., Olmstead, 527 U.S. at 607 . The Court held:

States are required to provide community-based treatment for persons with mental disabilities when the State's treatment professionals determine that such placcment is appropriate, the affected persons do not oppose such treatment, and the placement can be rcasonably accommodated, taking into account the resource available to the State and the needs of others with mental disabilities.

ld.

268. 532 U.S. 598 (2001). Buckhannon involved the plaintiff's challenge under the ADA to a West Virginia state law that all residents of board and care homes be capable of "self-preservation" in the event of emergencies. $I d$. at 600 . The Buckhannon home was closed because three residents were incapable of such self-preservation in the event of a fire or othcr catastrophe. Id. The suit was rendered moot two years after the filing when the state legislature eliminated the self-prcservation requirement. Id. at 601. The Fourth Circuit denied recovery of attorneys' fces, rejecting the so-called "catalyst theory." Buckhannon Bd. and Care Home, Inc. v. W. Va. Dep't of Health and Human Res., 203 F.3d $819,{ }^{*} 1$ (4th. Cir. 2000).

269. 29 U.S.C. $\S 12205(2000)$.

270. See, e.g., Marbley v. Bane, 57 F.3d 224, 234 (2d Cir. 1995), Kilgour v. Pasadena, 53 F.3d 1107,1010 (9th Cir. 1995), Zinn v. Shalala, 35 F.3d 273, 276 (7th Cir. 1994). 
the defendants conduct."271 Yet the majority in Buckhannon held that this was insufficient; to prevail, the lawsuit had to generate a change in the legal relations of the parties, either in the form of a final judgment or a consent decree. ${ }^{272}$ As in Garrett, the Buckhannon majority appeared to disregard legislative history that indicated that "[t]he phrase prevailing party is not intended to be limited to the victor after only a full trial on the merits." 273

The dissent fairly summarized Buckhannon's impact on Title II and civil rights litigation more generally:

The decision allows a defendant to escape a statutory obligation to pay a plaintiff's counsel fees, even though the suit's merit led the defendant to abandon the fray, to switch rather than fight on, to accord plaintiff sooner rather than later the principal redress sought in the complaint. Concomitantly, the Court's constricted definition of "prevailing party," and consequent rejection of the "catalyst theory," impede access to court for the less well heeled, and shrink the incentive Congress created for the enforcement of federal law by private attorneys general. ${ }^{274}$

An attorney prosecuting a Title II suit for injunctive relief can have no confidence in the prospect of recovering attorneys' fees, even if her case is a strong one and she can overcome the procedural hurdles mentioned above. The state defendant can, when all other attempts to thwart the litigation have failed, merely make whatever accommodation the plaintiff originally sought and thereby circumvent the attorneys' fees penalty for noncompliance. Alternatively, the state could settle privately with the individual plaintiff; such settlements may reduce the attorneys' reeovery to little or nothing. Few attorneys indeed are likely to bear the heavy burden of financing protracted litigation against a state, even in the best of cases, when their recovery hinges on the beneficence of the state defendant.

Second, and most important, states have no real incentive to comply voluntarily with Title II if they risk only injunctive costs. Averting possible litigation is a poor incentive for states to make the accommodations that people with disabilities need if the worst consequence of losing a lawsuit is that they will be forced to make the accommodation they were theoretically required to make in the first place. ${ }^{275}$ Although attorneys' fees, which remain available under Title II, have somewhat incentivized voluntary compliance with Title III because many of the small private business owners at risk have few cash reserves, such costs are not likely to intimidate a state

271. Buckhannon, 532 U.S. at 600

272. Id. at 604 .

273. Id. at 607 (quoting H.R. REP. No. 94-1558 at p.7).

274. Id. at 622-23 (Ginsberg, J., dissenting).

275. Attorneys' fees, which are recoverable under Title II, are unaffected by defective abrogation of sovereign immunity and remain available. 42 U.S.C. § 12205 (1994). 
like California, which has a projected budget in fiscal year 2003-2004 that exceeds one hundred billion dollars. From a purely economic standpointand in consideration of the massive costs a state would incur if it suddenly brought itself into full compliance with the letter of Title II of the ADA $^{276}$ - the most cost-effective course of action is to avoid making any changes voluntarily, to defend lawsuits vigorously, to avoid attorneys' fees awards under Buckhannon by making the requested accommodations if the litigation is going badly, or, as a last result, to make only those accommodations ordered by the courts. States' cost-benefit analyses also surely would take into consideration the depressing social and economic realities that led to the ADA's passage in the first place. These realities include the low education level of many people with disabilities (which correlates with their lack of awareness of their legal and constitutional rights), their collective financial destitution resulting from high unemployment (which undermines their ability to finance expensive lawsuits), ${ }^{277}$ and their frequent isolation (which makes it less likely that they will learn of their legal rights or obtain legal support from third parties). ${ }^{278}$

The convergence of the numerous substantive and procedural limitations on private Young suits brought under the ADA leaves little hope that such actions will be filed with any frequency, or that they can spur voluntary compliance by scofflaw states. These limitations are myriad. The narrow prospective scope of injunctive relief under Young, the unavailability of jury trials, the burden on the Title Il plaintiff to show a substantial likelihood of discriminatory harm at the hands of the same state defendant, and the fact that plaintiffs bear most of the risk in such a suit all cut against the viability of Young suits. Further, defendants can engage in a judiciallysanctioned game of "chicken" with these disabled plaintiffs since Buckhannon allows them, if all other litigation strategies fail, to still avoid attomcys' fees by complying with the law at the last possible minute. In addition to these factors, we must consider as well the reality that some circuits, such as the Fifth and Seventh, hold that state officers cannot be liable under Young as a matter of law. In light of all of these reasons and the inherent and substantial wealth disparity strongly favoring states over private Title II plaintiffs, Chief Justice Rehnquist's claim that Ex parte Young suits remain a viable basis to enforce ADA rights after Garrett strains credibility.

276. See, e.g., Bazar, supra note 239, at Al (detailing massive noncompliance with access guidelines by state agencies in California).

277. Supra note 264.

278. See supra note 40. 


\section{Scraping the Bottom of the Barrel: The Rehabilitation Act, State Law Remedies, and Section 1983}

So, assuming that monetary damages are unavailable and that claims for injunctive relief under Young have scant utility, where can plaintiffs turn? This Section briefly notes that none of the obvious remaining alternatives-the Rehabilitation Act, state law remedies, and individual liability suits brought under section 1983-can fill the significant void left in Title II as a result of defective abrogation of state immunity.

Because the Rehabilitation Act of $1973^{279}$ (the predecessor to the ADA) governs all entities that receive financial assistance, it is possible that money damages still may be available against states under this statute regardless of whether the Supreme Court eventually explicitly holds Title II invalid (as it seemed poised to do when it granted certiorari in Hason). According to the Ninth Circuit, money damages are still available under the Rehabilitation Act, ${ }^{280}$ as the Act validly abrogated sovereign immunity. However, the court came to this decision via exactly the same reasoning that led it to uphold Title II in Dare. Thus, the holding may not receive much deference from the Supreme Court in a future case on this question. Some circuits have held that the Rehabilitation Act was passed under the Spending Clause and that states expressly waive sovereign immunity as a condition of receiving federal funds. ${ }^{281}$ But other circuits have held that states do not necessarily waive sovereign immunity by accepting federal funds and that the Rehabilitation Act does not enable plaintiffs to circumvent Garrett's sovereign immunity holding. ${ }^{282}$ The split of authority over the availability of money damages under the Rehabilitation Act remains a source of incoherence in the law and affirms the ongoing significance of Title II and the abrogation issue.

Professors Colker and Milani have concluded that state laws may soon provide the only real means to address state disability discrimination. Yet, their in-depth research of state statutes targeting state discrimination indicated that only twenty-four states had clear statutory language prohibiting discrimination in facilities as well as programs and services. ${ }^{283}$ While most states had policies regarding physical access to public buildings and facilities, only fiftecn had private enforcement mechanisms (that is, private

279. 29 U.S.C. $\$ 794(2000)$

280. See Clark v. California, 123 F.3d 1267, 1270 (9th Cir. 1997).

281. See, e.g., Jim C. v. United States, 235 F.3d 1079 (8th Cir. 2000); Stanley v. Litscher, 213

F.3d 340, 344 (7th Cir. 2000); Pederson v. La. State Univ., 213 F.3d 858, 875-76 (5th Cir. 2000).

282. See, e.g., Garcia v. S.U.N.Y. Health Scis. Ctr., 280 F.3d 98, 113-14 (2d Cir. 2001); Reickenbacker v. Foster, 274 F.3d 974 (5th Cir. 2001); Koslow v. Pennsylvania, 158 F. Supp. 2d 539 (E.D. Pa. 2001). These opinions all held that acceptance of federal funds under the Rehabilitation Act did not result in waiver of state sovereign immunity.

283. Colker \& Milani, supra note 55, at 1084. 
causes of action) to assure compliance. ${ }^{284}$ Moreover, few states had mechanisms to police aceess to programs. And only twenty-four states addressed discrimination in terms of services. ${ }^{285}$ Colker and Milani's research is most devastating in its showing of anemic state remedies. Nine states had no enforcement mechanism whatsoever, ${ }^{286}$ and seven others offer only those remedies that would be available under Title II of the ADA. ${ }^{287}$ Finally, even where states may have an adequate remedial scheme, coverage may be inadequate vis-à-vis the ADA. For example, Alabama's public accommodation limitation only reaches persons with physical disabilities, leaving a huge number of persons with mental disabilities without any legal protection whatsoever. ${ }^{288}$ In sum, state laws are not only inherently incapable of creating a uniform national standard of treatment for the disabled, they also are unlikely to generate the kind of barrier removal and programmatic access at the state level that Title II was designed to create.

Another possible means of vindicating access rights of the disabled is to use section $1983 .{ }^{289}$ It is well established that a plaintiff also may bring a claim for money damages under section 1983 against a state official for a violation of a federal statutory or constitutional right that is made under "color of state law." ${ }^{\text {"290 }}$ These suits do not implicate the Eleventh Amendment or state sovereign immunity because the liability is individual, and not "official," and the state is not paying the damage award. ${ }^{291}$ As the Supreme Court made clear in Alden v. Maine, the wrongful conduct must be "fairly attributable to the officer himself." 292

284. Id. at $1087 \mathrm{tbl}, 1$ (showing findings of state policies on physical access).

285. Id. at 1092 n. 42 .

286. Id. at 1102 . These states included predominantly southern and rural states like Mississippi, Georgia, Utah, and Idaho. It should be noted that "no enforcement mechanism" in the authors' eyes means that states at most can receive a misdemeanor penalty. See id.

287. Id.

288. Id. at 1104 .

289. Section 1983, 42 U.S.C. $\$ 1983(2000)$, states:

Every person who, under color of any statute, ordinance, regulation, custom, or usage, of any

State or Territory or the District of Columbia, subjects, or causes to be subjected, any citizen of the United States or other person within the jurisdiction thereof to the dcprivation of any rights, privileges, or immunities seeured by the Constitution and laws, shall be liable to thc party injured in an action at law, suit in cquity, or other proper proceeding for redress.

290. See Scheuer v. Rhodes, 416 U.S. 232 (1974). Scheuer involved wrongful death claims brought by the families of thrce vietims of the notorious Kent State shootings. They filed section 1983 claims against the Governor of the State of Ohio, the Adjutant General of the National Guard, his assistant, and the president of Kent State. Id. at 234. The court held that Elcventh Amendment immunity did not bar suits for damages against the individual state officials for their own individual violations of federal constitutional rights "under color of state law" so long as the damages are paid by the individual himself. Id. at 238. See also Maine v. Thiboutot, 448 U.S. I, 4-8 (1980) (extending liability for individual state offieers to federal statutory rights).

291. See Kentucky v. Graham, 473 U.S. 159, 165-67 (1985) (distinguishing between individual suits under section 1983, in which damages are paid by the individual state official, and "official" suits, in which judgments will be paid with money from state eoffers).

292. 527 U.S. 706, 757 (1999). 
However, section 1983 does not provide much hope for Title II plaintiffs either. While section 1983 serves as an important tool for deterring police brutality and other egregious civil rights violations by state officials by putting them on notice that they may have to pay the cost of individual wrongs, ${ }^{293}$ this type of action is not suited to enforcing the ADA's accommodation mandates and has little chance of fostering compliance. It is hard to conceive of a decision by a state individual not to provide a telecommunications device, not to install a ramp, or not to make a service accessible as rendering her individually liable since all of these decisions are essentially a function of policy. The bureaucratic performance of one's normal official functions (albeit in a way that burdens the disabled under Title II) bears little resemblance to the kind of snap judgments or out-of-control decisions by law enforcement (for example, to beat up an innocent civilian, trash a personal residence, or manhandle a suspect during interrogation) that typically result in individual liability. Decisions by bureaucrats that disadvantage the disabled will rarely, as Alden requires, be fairly attributable to the individual state officials themselves. Section 1983 deters constitutional and statutory abuses because in the paradigmatic scenario a state official exploits his discretion in a way that is inconsistent with policy (as well as the law). It is the departure from policy that renders the liability "individual" instead of "official." Yet, the very types of decisions implicated by Title II are ministerial and will almost always reflect policy rather than detract from it. Decisions not to make accommodations are not likely to be rogue in the same way as is police misconduct.

Furthermore, some courts have held that section 1983 cannot be applied to enforce Title II or Rehabilitation Act suits because the statutes do not countenance individual liability. For example, the Eighth Circuit in Alsbrook held that the ADA's remedial scheme is exclusive based on Congress's failure to include section 1983 suits into the remedies in Title II of the Civil Rights Act upon which the ADA's remedies are based. ${ }^{294}$

In sum, section 1983 suits are structurally incompatible with the ADA's accommodation mandate and provide no substitute for the weak Young remedy discussed above. It is questionable whether Congress intended section 1983 claims to be available under the ADA. Even if we ignore this significant legal issue, how can the type of programmatic or

293. See Bivens v. Six Unknown Named Agents of Fed. Bureau of Narcotics, 403 U.S. 388 (1971) (allowing section 1983 claims against federal drug agents for disregard of Fourth Amendment rights where they entered plaintiff's home without a warrant, searched it, and arrested the plaintiff, shaekling him in front of his family and threatening to arrest them as well).

294. See Alsbrook v. City of Maumelle, 184 F.3d 999, 1010-12 (8th Cir. 1999) (en banc). See also Holbrook v. City of Alpharetta, 112 F.3d 1522, 1531 (1lth Cir. 1997) (holding that no section 1983 claim was available under Rehabilitation Act remedies). Cf. Pathways Psychosocial v. Town of Leonardtown, 223 F. Supp. 2d 699, 707-08 (D. Md. 2002) (emphasizing that constitutional deprivations remained actionable under section 1983 regardless of the preemption theory underlying the Alsbrook decision). 
facilities-related decisions targeted by Title II made by bureauerats ever be fairly characterized as individual in nature? Is it reasonable to think that bureaucrats will suddenly order all state department of motor vehicles offices to install accessible bathrooms or produce every state pamphlet in Braille out of fear that failure to do so will subject them to personal liability?

\section{CONCLUSION}

Unquestionably, the dignitary harms that result from discrimination by public entities have special symbolic significance. ${ }^{295}$ A driving force of the Civil Rights Act of 1964 was the premise that our government must lead the charge in eliminating segregation of ethnic minorities lest its mandate of equal protection for private actors ring hollow. The same reasoning surely applies today for the public entities covered by Title II of the ADA. If state governments are able to disobey the civil rights law with impunity, or, even worse, are held to a lower standard than private businesses, America faces an unacceptable double standard. ${ }^{296}$

Building from the premise that Title II integration and access lawsuits are a central equalizing tool for America's disability rights community and the Independent Living Movement, ${ }^{297}$ I have asked whether Title Il can function effectively without a monetary damage award. The Garrett majority implied that it can. The Court reasoned that Congress's defective abrogation of sovereign immunity was not necessarily fatal to Title I because equitable remedies remain available. ${ }^{298}$ Yet, as I have discussed, injunctive suits filed against state officers under Young likely will not lead to the kind of equal access to public programs, services, and facilities that Congress

295. Certainly, the impact of inaccessible transportation and facilities goes far beyond the individual with a disability herself. Indeed, many of the able-bodied individuals who dominate private enterprise, political institutions, local government, and civic associations have come to view individuals with disabilities as members of a largely nonparticipatory group, with whom they have limited contact. lsolation of the disabled reinforces existing stereotypes that the disabled are socially, politically, and economically inferior or are to be pitied. See generally JAMES I. CHARLTON, Nothing ABOUT US Without Us: Disability OPPRESSion and Empowerment (1998); Joseph P. SChapiro, No Pity: People with Disabilities Forging a New Civil Rights Movement (1993).

296. Cf. Guy Wallace \& Carol Bradley, Gov. Davis' Lawsuit Puts Equal Rights at Risk, S.F. Chron., June 26, 2000, at A21. The authors speculated on thc far-reaching effects if Title II were declared invalid and noted that:

[i]f those with disabilities are not able to access such facilities and services, they will be denied opportunities fundamental to their physical health and ability to earn a living. For example, a child who uses a wheelchair cannot go to school if there is no ramp into the school building. Obviously, if a child cannot even enter the school, it will be impossible for the child to attain the high school diploma needed to enter today's workforce. Without Title 11, that child may end up on welfare.

Id.

297. See, e.g., SCHAPIRO, supra note 295, at 46-58 (providing background on the Independent Living Movement).

298. Bd. of Trs. of Univ. of Ala. v. Garrett, 531 U.S. 356, 374 n.9 (200I). 
originally envisioned when it passed the ADA. Assuming, as I argue here, that Garrett's analytic approach to Section 5 legislation must govern Title II alongside Title I, few plaintiffs will have the incentive to pursue potentially costly Title Il litigation. Even if the Second Circuit's view that a plaintiff can still recover money damages for intentional discrimination after Garrett by using either McDonnell Douglas's "pretext" or Price Waterhouse's "mixed motive" framework garners support from other circuits, the allocation of burdens seems inappropriate for the disabled, who are entitled only to rational basis review as the Court made clear in Garrett and Heller.

There are many important procedural burdens faced by a Title II plaintiff seeking injunctive relief under Young, including the lack of jury trials and the need to prove a substantial likelihood of similar discriminatory harm by the same state in the future. These are powerful disincentives to both litigation and voluntary compliance. Even if the plaintiff can overcome such burdens, there are certain jurisdictions that hold that the ADA applies narrowly to "public entities" and hence Young suits against state officers in their official capacities are unavailable.

Moreover, since the Supreme Court's retrenchment of what constitutes "prevailing party" in Buckhannon (under which a plaintiff is not treated as a prevailing party if a state voluntarily corrects a Title II violation in response to litigation), attorneys' fees are only available where there is either a consent decree or a final judgment on the merits (to wit, a change in the legal relationship of the two parties). As I pointed out, even the most altruistic attorneys with well-known impact litigation groups like DREDF, are not likely to be interested in pursuing claims when the mere last-minute act of compliance (like some deathbed confession) can cause their hard-earned fee awards to evaporate. Additionally, we must remain mindful of the reality that, much like large corporations, states have deep pockets (except that, unlike private businesses, the money they spend is not their own and they arguably therefore have less attachment to it). This important disparity in resources enables states to protract litigation; they can typically outspend and out-staff their opponents.

Finally, the void in Title Il cannot easily be filled by the most obvious alternatives. First, even though the Rehabilitation Act is an obvious default statute, since all states will be covered as all of them receive federal financia! assistance, Title II's value was its far greater level of detail. Furthermore, as I pointed out, there are some jurisdictions that treat the Rehabilitation Act as having failed to validly abrogate state immunity on the same reasoning that I have applied here to Title II. Second, state law remedies, aside from lacking uniformity, are substantially inadequate in many cases. Third, section 1983 suits, which some jurisdictions hold to be unavailable as a matter of statutory construction, were conceived to prevent 
civil rights abuses by officials who break with policy usually at the ministerial level. Since Title II claims by nature target policy-level decision making, individual liability is implausible.

With the grant of certiorari in Hason, it is difficult to understand why the Supreme Court went out of its way not to rule on Title II in Garrettleaving a circuit split in place-only to attempt to take up the question two years later. The Garrett majority's implications to the contrary, noncompliance with Title II of the ADA by states remains a real and serious problem, ${ }^{299}$ however "anecdotal" the evidence in the legislative record might have seemed to the Court. To the extent that Chief Justice Rehnquist and his colleagues still believe that Ex parte Young provides a means for disabled plaintiffs to enforce Title II's access mandate by suing state officers in their official capacities, they should make this clear and eliminate existing inconsistencies among lower courts on this question. For barrier removal to take place it is clear that Title II must be backed up by some meaningful enforcement mechanism. Without physical and programmatic access, the disabled will remain perhaps America's most segregated minority.

299. See, e.g., Bazar, supra note 239 , at A1. The artiele notes that a "survey of the state's 10 largest departments shows that California government clearly violates the 1990 Americans with Disabilities Act and is at least a decade away from ensuring that the public has unencumbered access to its programs and facilities." Id. The artiele noted that state hospitals, as well as other Title 11-covered state entities like the Department of Health Services and agencies such as the Department of Developmental Services, laek ramps and wheelchair-accessible doorways. Id. 